\title{
Cumulative Impact Index for the Adriatic Sea: Accounting for interactions among climate and anthropogenic pressures
}

\author{
Elisa Furlan ${ }^{\mathrm{a}, \mathrm{b}}$, Silvia Torresan ${ }^{\mathrm{a}, \mathrm{b}}$, Andrea Critto ${ }^{\mathrm{a}, \mathrm{b}, *}$, Tomas Lovato ${ }^{\mathrm{b}}$, Cosimo Solidoro ${ }^{\mathrm{c}, \mathrm{d}}$, \\ Paolo Lazzari ${ }^{c}$, Antonio Marcomini ${ }^{\mathrm{a}, \mathrm{b}}$ \\ a Department of Environmental Sciences, Informatics and Statistics, University Ca' Foscari Venice, I-30170 Venice, Italy \\ ${ }^{b}$ Fondazione Centro-Euro-Mediterraneo sui Cambiamenti Climatici (CMCC), I-73100 Lecce, Italy \\ ${ }^{c}$ National Institute of Oceanography and Experimental Geophysics (OGS), I-34010 Sgonico, Trieste, Italy \\ ${ }^{\mathrm{d}}$ International Centre for Theoretical Physic (ICTP), I-34010 Trieste, Italy
}

\section{H I G H L I G H T S}

- Integrated index to evaluate cumulative impacts posed by interactive pressures

- Cumulative impacts are identified for reference and future scenarios.

- Higher cumulative impacts are mainly evident in the North Adriatic Sea.

- Rising cumulative impact scores in the future climate change scenario

- Results could support integrated maritime spatial planning and climate adaptation.
G R A P H I C A L A B S T R A C T

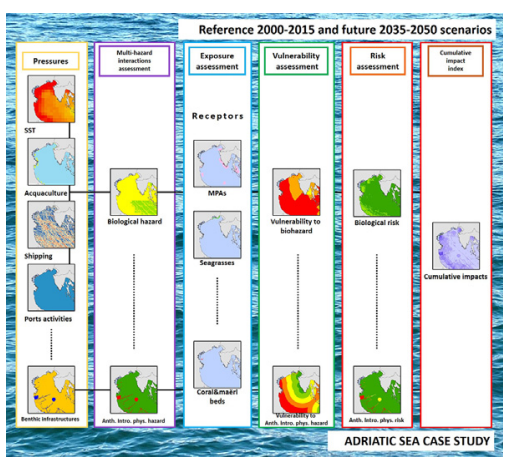

\section{A R T I C L E I N F O}

\section{Article history:}

Received 8 January 2019

Received in revised form 27 February 2019

Accepted 2 March 2019

Available online 3 March 2019

Editor: Damia Barcelo

\section{Keywords:}

Cumulative impacts

Interactive pressures

Climate change scenarios

Multi-Criteria Decision Analysis

Geographic Information Systems

Adriatic Sea

\begin{abstract}
A B S T R A C T
Assessing and managing cumulative impacts produced by interactive anthropogenic and natural drivers is a major challenge to achieve the sustainable use of marine spaces in line with the objectives of relevant EU acquis. However, the complexity of the marine environment and the uncertainty linked to future climate and socioeconomic scenarios, represent major obstacles for understanding the multiplicity of impacts on the marine ecosystems and to identify appropriate management strategies to be implemented. Going beyond the traditional additive approach for cumulative impact appraisal, the Cumulative Impact Index (CI-Index) proposed in this paper applies advanced Multi-Criteria Decision Analysis techniques to spatially model relationships between interactive climate and anthropogenic pressures, the environmental exposure and vulnerability patterns and the potential cumulative impacts for the marine ecosystems at risk. The assessment was performed based on spatial data characterizing location and vulnerability of 5 relevant marine targets (e.g. seagrasses and coral beds), and the distribution of 17 human activities (e.g. trawling, maritime traffic) during a reference scenario 2000-2015. Moreover, projections for selected physical and biogeochemical parameters (temperature and chlorophyll ' $a$ ') for the 2035-2050 timeframe under RCP8.5 scenario, were integrated in the assessment to evaluate index variations due to changing climate conditions. The application of the CI-Index in the Adriatic Sea, showed higher cumulative impacts in the Northern part of the basin and along the Italian continental shelf, where the high concentration of human activities, the seawater temperature conditions and the presence of vulnerable benthic habitats, contribute to increase the overall impact estimate. Moreover, the CI-Index allowed understanding which are the
\end{abstract}

\footnotetext{
* Corresponding author at: Informatics and Statistics, University Ca' Foscari Venice, Via Torino 155, 30170 Venezia-Mestre, Italy.

E-mail address: critto@unive.it (A. Critto).
} 
phenomena contributing to synergic pressures creating potential pathways of environmental disturbance for marine ecosystems. Finally, the application in the Adriatic case showed how the output of the CI-Index can provide support to evaluate multi-risk scenarios and to drive sustainable maritime spatial planning and management.

(c) 2019 Elsevier B.V. All rights reserved.

\section{Introduction}

Efforts to achieve the good environmental and ecological status of the marine and coastal environment, in line with the relevant EU acquis (EC, 2008; European Parliament, 2001) require appropriate policies that cannot be designed without a comprehensive knowledge of the impacts induced by different natural and anthropogenic drivers. In fact, the growth of maritime activities is taking place without the full understanding of the complex interactions between natural and humaninduced changes, leading to a progressive decline of biodiversity, and consequently, the degradation of marine ecosystems. Moreover, if pressures are considered individually, they may appear to be at sustainable levels, while their overall impact may be considerable if they take place in the same area, acting on the same vulnerable habitats (HELCOM, 2017).

Improving our capacity to model and evaluate the combined effects of multiple stressors, in decisional contexts characterized by high uncertainty linked to natural dynamics difficult to predict, is therefore essential to address the future planning and management of our seas.

In the latest years several European and International projects were funded for developing methodological approaches aimed at evaluating cumulative impacts and risks produced by both natural and anthropogenic pressures on marine areas (e.g. HELCOM TAPAS ${ }^{1}$ and SPICE ${ }^{2}$, Adriplan $^{3}$, COCONET $^{4}$, PERSEUS $^{5}$, HARMONY $^{6}$, PEGASO $^{7}$, Massachusetts Ocean Management $\operatorname{Plan}^{8}$ ). However, despite the awareness of the interactive and complex nature of pressures in dynamic ecosystems, such as marine areas, documented by numerous empirical and correlational studies (Crain et al., 2008; Sundbäck et al., 2007; Torquemada et al., 2005; Nordemar et al., 2003), most of the developed methodologies, basically inspired by the approach proposed by Halpern et al. (2008), have assumed an additive accumulation of impacts associated to single stressors (Halpern et al., 2008; Ban et al., 2010; Kappel et al., 2012; Korpinen et al., 2012; Andersen et al., 2013; Breton et al., 2014; Depellegrin et al., 2017; Gissi et al., 2017; HELCOM, 2017; Bevilacqua et al., 2018; Menegon et al., 2018a, 2018b). Among these, only few studies have tried to include in the assessment more complex pathways of interactions between local and global stressors (i.e. synergic and antagonistic) through the application of specific aggregation functions and modelling tools (Ban et al., 2014; Brown et al., 2014; Foden et al., 2011; Canu et al., 2011; Stelzenmüller et al., 2009). Moreover, cumulative impacts induced by alternative scenarios of interactions, based on envisioned management measures and climate projections, have been rarely explored (Berry et al., 2015; Brown et al., 2014; Stelzenmüller et al., 2010; Canu et al., 2010), thus limiting the assessment to a snapshot in time based recent/current conditions. These limitations are reflected in the mainstream traditional (and current) marine

\footnotetext{
1 http://www.helcom.fi/helcom-at-work/projects/completed-projects/tapas.

2 http://www.helcom.fi/helcom-at-work/projects/completed-projects/spice.

3 http://www.adriplan.eu/.

4 Towards COast to COastNETworks of marine protected areas (from the shore to the high and deep sea), coupled with sea-based wind energy potential.

5 Policy-oriented marine Environmental Research for the Southern European Seas.

6 'Development and demonstration of Marine Strategy Framework Directive tools for harmonization of the initial assessment in the eastern parts of the Greater North Sea sub-region.

7 People for Ecosystem Based Governance in Assessing Sustainable Development of Ocean and Coast.

8 http://www.seaplan.org/.
}

management and planning approach, applying sectorial perspectives according to individual economic sectors' objectives ('sectoral zoning'; Douvere, 2008), already proved to be unsuccessful in advancing the sustainable use of the marine environment. Being focused on managing individual activities separately from each other, they fail to account for their interactions and conflicts, as well as to analyze the resulting cumulative impacts on marine ecosystems (Kelly et al., 2018).

Moving beyond the traditional cumulative impact assessment methodologies and the recently developed multi-hazard approach described in Furlan et al. (2018), this paper aims at presenting a Cumulative Impact Index (hereafter CI-Index) integrating different metrics and scenarios of climate, ocean, biogeochemical and anthropogenic pressures (e.g. temperature variation, shipping traffic, aquaculture, ports activities, nutrients input) to evaluate cumulative impacts produced by interactive pressures in the Adriatic Sea case study area. Compared to the approach presented in Furlan et al. (2018), the key novelty of the CIIndex lies on the identification and evaluation of interactions and possible cumulative impacts induced by climate-related drivers (e.g. sea surface temperature variation) in combination with local to regional anthropogenic pressures (i.e. shipping traffic, aquaculture activities, chemical pollution by oil-spill). Its implementation, in fact, requires the application of the Choquet integral (Choquet, 1954; Murofushi and Sugeno, 1989; Grabisch, 1996; Zabeo et al., 2010; Giupponi et al., 2013) to model complex environmental phenomena induced by interactive pressures (e.g. biological disturbance through the introduction of non-indigenous species) and to, finally, develop a set of spatial maps and indicators identifying vulnerable hot-spots (e.g. seagrasses meadows, coral and maërl beds) requiring appropriate management actions and adaptation strategies for ecosystems' restoration and protection. Another element of novelty respect to Furlan et al. (2018) is the integration of a climate change scenarios in the CI-Index for a subset of pressures (i.e. sea surface temperature and nutrient input). This allowed calculating the $\mathrm{CI}$-Index both for a reference (i.e. 2000-2015) and for a future timeframe (2035-2050) in order to support mid-term adaptive management of the Adriatic Sea.

After a brief introduction to the case study area and the input dataset used in the assessment (Section 2), the paper illustrates the key operational steps of the development of the CI-Index (Section 3) and, finally, presents the main results, including GIS-based maps and statistics useful to drive marine resources management and maritime spatial planning.

\section{Study area and spatial data for the CI-Index application}

\subsection{The Adriatic Sea case study}

The CI-Index was applied in the marine sub-region of the Adriatic Sea, a semi-enclosed basin of the Mediterranean Sea, connected to the Ionian Sea through the Strait of Otranto (Fig. 1). Located among the Italian and the Balkan peninsulas, it is surrounded by six coastal States: Albania, Bosnia and Herzegovina, Croatia, Italy, Slovenia and SerbiaMontenegro. It is featured by a stretched shape extending in northwest south-east direction, with a major axis with a length of $800 \mathrm{~km}$ and a minor one of about 150-200 km (Policy Research Corporation, 2011; Ramieri et al., 2014). The basin covers a total surface of $138,600 \mathrm{~km}^{2}$ and an estimate volume of about 33,000 $\mathrm{km}^{3}$ (Buljan and Zore-Armanda, 1979). 


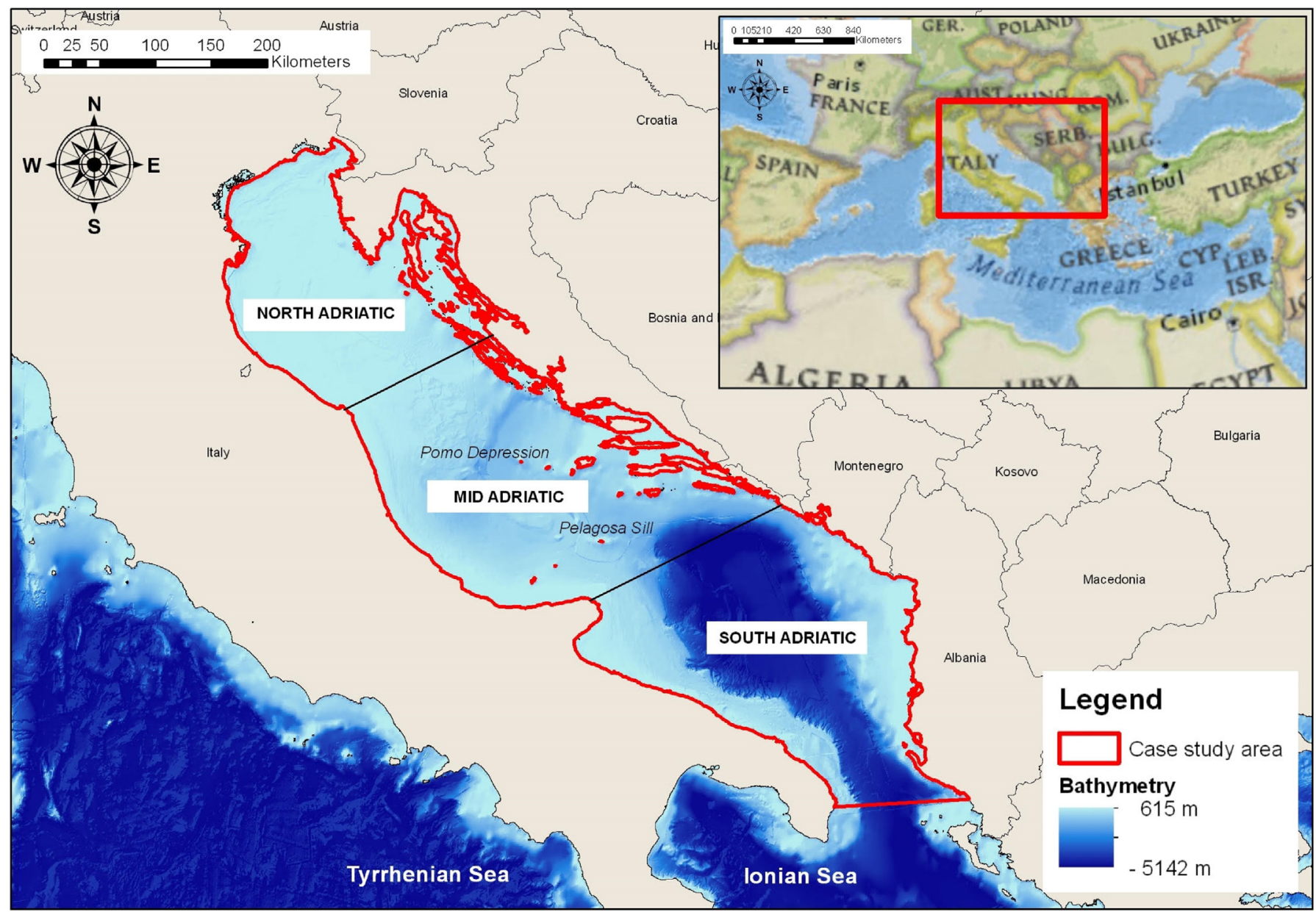

Fig. 1. The Adriatic Sea case study area.

The clear morphological differences occurring both along the longitudinal and transversal axes, allow to ideally divide the Adriatic Sea into three main geographic areas: northern, central and southern subbasins (Fig. 1).

More specifically, the first one extends from the northernmost part (up to Trieste and Venice) to the $100 \mathrm{~m}$ bathymetric line, located approximately in front of the city of Giulianova (Italy). This area is featured by a very low average depth (about $30 \mathrm{~m}$ ) and a weak bathymetric gradient, with bottoms that slope gently in the south-east direction (Van Straaten, 1970; Trincardi et al., 1996). The central Adriatic sub-basin marks the transition zone between the northern and southern subbasin, and from a morphological point of view it is mainly marked by the presence of the "Meso-Adriatic Trench", shaped by the Pomo Depression, a complex transverse depression featured by high biodiversity. This area is finally connected with the deepest South Adriatic through the Pelagosa Sill. This third zone, characterized by a wide abyssal depression (i.e. the South-Adriatic depression), extends from the Pelagosa Sill to the Strait of Otranto which divides the Adriatic from the deepest Ionian Sea.

The great morphological and hydrological diversity of the Adriatic Sea makes it a marine sub-region with a high diversity in terms of productivity and biodiversity (Cerrano et al., 2016). In fact, with over than 7.000 native species (many of them endemic and rare), of which 410 species and subspecies of fish (Lipej and Dulčić, 2004), and the presence of 4 of the 5 seagrasses species recorded in the Mediterranean (Koce et al., 2003), the Adriatic is regarded as the most productive area across the whole Mediterranean region (Bastari et al., 2016; Casellato and Stefanon, 2008; Guidetti et al., 2002). Seagrasses meadows are one of the most important biocenoses in the basin, exercising a multifunctional role, contributing, on one side, to the productivity and biodiversity of coastal area (Waycott et al., 2007), and on the other one, in preventing erosion through the consolidation of seabed and the attenuation of motion wave (ISPRA, 2012c). Mainly located along the Eastern side of the basin (Gamulin-Brida, 1974), also coral beds and maërl facies represent, as seagrasses, biodiversity "hot-spots", able to improve biological and functional diversity of coastal sediments (Cerrano et al., 2016). This remarkable marine biodiversity represents, for the Adriatic Sea, a great environmental resource but also makes it a highly threatened ecosystem, since often over-used for direct ecosystem services production (e.g. seafood) and natural resources exploitation (e.g. sands and gravel extraction). Moreover, the great beauty of the Adriatic Sea makes it an attractive place to live and work: it is estimated that more than 3,5 million people live on its shores, to be added to the rising number of tourist deciding to spend their holidays on these zones (Ramieri et al., 2014).

The high urbanization linked with tourism, and the related coastal development have led, in recent decades, to a drastic change of coastal zones and a gradual increase of marine pollution (Foley et al., 2010; Ramieri et al., 2014). In fact, several areas in the basin are affected by spills of untreated wastewaters and solid waste from land-based activities, as well as pollution events related to oil spill release (Pavlakis et al., 2001; Ferraro et al., 2007; Kirby and Law, 2010), gas extraction and dumping of fertilizers from inland farms (Degobbis, 1989; Rossi et al., 1992). The Adriatic Sea also represents an important maritime transport route used by merchant ships (in national and international trade), fishing boats, yacht and military ships. It should be noted, even more, that along the Western Adriatic coasts is located a significant number of industrial centers depending on the Adriatic ports (e.g. Trieste, Venice and Koper) for export and import of goods. Activities 
depending on shipping traffic are one of the driver of underwater acoustic pollution, as well as water contamination and marine litters production (Suaria and Aliani, 2014; Strafella et al., 2015; Munari et al., 2016; Suaria et al., 2016). Moreover they are well-recognized as main vector of biological disturbance through invasive species introduction, taking place by means of ballast waters' discharge by ships (De Poorter et al., 2010; Keller et al., 2011; Kuhlenkamp and Kind, 2018). The Adriatic Sea is also a fruitful area for fish stocks of commercial value. Fishing, including multi-gear activity, ranging from small scale activities like artisanal fishery, to demersal trawling and pelagic mid-water trawling at a larger scale, has been traditionally an important sector for the economies of most Adriatic countries. However, trawling is one of the most important source of human-induced physical disturbance on benthic communities (seabed abrasion), with long-term impacts negatively affecting structure and functioning of seafloor ecosystem. Finally, another relevant economic activity relates to LNG (Liquefied Natural Gas) terminals and offshore platforms for oil and gas extraction, spread in the whole basin. The presence of such infrastructures, besides leading to smothering and sealing of benthic communities, as well as space competition with other maritime activities (e.g. fishing is forbidden around terminals and platforms), it represents a hot-spot risk area potentially contributing to marine chemical accidents with high effects on surrounding natural habitats.

On this complicated scenario of multiple and overlapping humanmade pressures, climate change is posing an additional exogenic stress (i.e. induced by natural drivers operating outside the control of management measures) (Elliott et al., 2015) through rising sea levels, increased sea temperatures and ocean acidification (IPCC, 2014). The basin is known to have a large spatial and temporal variability (both seasonal and interannual) depending on its driving forcing (atmospheric and land-based). As example, sea temperature parameter shows largescale variations with a clear seasonal cycle with values fluctuating from 22 to $30{ }^{\circ} \mathrm{C}$ during summer and from 12 to $14{ }^{\circ} \mathrm{C}$ during winter (Zore-Armanda, 1983). In particular, the frequency and severity of temperature extreme events are expected to increase in the next decades within the Mediterranean area, leading to significant impacts on marine benthic communities (Galli et al., 2017). Similar ranges of variabilities are observed as well for most biogeochemical parameters (Solidoro et al., 2009). Climate change is an issue of relevant concern for the Adriatic Sea due to both the vulnerability of important ecosystems, such as seagrasses and coral beds (Zunino et al., 2017), and the confluence of cultural and socio-economic values.

\subsection{Dataset for the CI-Index application}

The implementation of the $\mathrm{Cl}$-Index has required the collection and processing of a huge amount of heterogeneous spatial data collected from different web-data platforms and recently accomplished EU and national projects. As described in Furlan et al. (2018), retrieved spatial layers belong to two main categories: i) physical and environmental data, including site-specific socio-economic and bio-geo-physical information allowing selection and mapping of key marine targets (e.g. seagrasses, marine protected areas) and vulnerability factors; ii) endogenic and exogenic drivers, supporting spatial modelling of distribution and intensity of climate-related and human made hazards and pressures. Compared to Furlan et al. (2018), additional data regarding sea surface temperature (SST) and the chlorophyll 'a' variation (Chl), were collected to investigate potential variations of the CI-Index in a future climate scenario. Specifically, (SST) data were provided by the Foundation Centro Euro-Mediterraneo sui Cambiamenti Climatici (CMCC Foundation, www.cmcc.it) (Lovato et al., 2013; Oddo et al., 2014), whereas information on the chlorophyll 'a' variation (Chl) (used for mapping nutrients input) by the National Institute of Oceanography and Experimental Geophysics (OGS, www.ogs.trieste.it) (Lazzari et al., 2014, 2016; Canu et al., 2015). Both datasets were provided for a reference and future climate change scenarios (i.e. 2000-2015 and 2035-2050), in order to evaluate effects induced by changing climate conditions on the overall CI-Index. Climate projections were developed under the RCP8.5 (Representative Concentration Pathways), representing rising radiative forcing pathway leading to $8.5 \mathrm{~W} / \mathrm{m}^{2}$, due to an envisioned 2100 scenario including the absence of climate change policies and the increasing energy demand and GHG concentration. As a consequence, the SST and Chl 'a' projections represent the worst scenario in terms of radiative forcing (cumulative measure of human emissions of GHGs from all sources) (Riahi et al., 2011), thus applying in the assessment a highly precautionary perspective to spatial mapping of marine pressures linked to these variables. Finally, since the evaluation of potential effects induced by temperature and nutrients input variation was focused on shallow benthic habitats (i.e. seagrasses meadows and coral and maërl beds), data at the sea surface were considered suitable to represent sea water variations at the case study level (Okey et al., 2015).

As reported in the Table 1, the available dataset allowed the investigation of 6 types of hazards, representing human-derived pressures causing either temporary or permanent physical disturbance, loss or damage to one or several components of an ecosystem, was selected. Pink cells highlight physical impacts (i.e. physical damages and losses by abrasion and sealing of the seabed); the green one the biological impacts (i.e. biological disturbance by, the introduction of non-indigenous species); and the orange cells the chemical ones (i.e. chemical acute and chronic sea pollution by oil-spill and nutrients input). Driving-forces, pressures and hazard metrics were then identified for each hazard, according to the Italian Initial Assessment Reports (ISPRA, 2012a, 2012c, 2012d) reporting, for all pressures listed in the Marine Strategy Framework Directive (EC, 2008), a set of stressors and indicators useful for the assessment of the marine environmental state.

Overall, the hazards selected for the application of the CI-Index allow the evaluation of the combined effects of more localized endogenic pressures (e.g. port activities, aquaculture) and diffuse exogenic ones (e.g. SST variations) often interacting with each other's. However, other emerging hazards affecting the case study, such as the input of marine litter, were not integrated in the assessment due to the limited availability of data covering the whole basin. Moreover, even if the MSFD doesn't explicitly account for climate change, despite it was given greater prominence in the proposed Directive (EC, 2005), the list of pressures was expanded considering the SST variation as relevant metric to evaluate potential cumulative effects of climate change with more localized endogenic pressures.

\section{The CI-Index: conceptual framework and methodological steps}

The main objective of the CI-Index is to assess cumulative impacts posed by interactive natural and anthropogenic pressures affecting marine areas. More specifically, the index aims at identifying, ranking and mapping multiple sources of hazard, habitats and targets at risk and, finally, to evaluate areas more prone to cumulative environmental impacts in the marine region of concern (Hayes and Landis, 2004).

The following sections describe the CI-Index conceptual framework (Section 3.1) and its application procedure highlighting input data and mathematical equations applied in the Adriatic Sea case study, for the reference (2000-2015) and future scenario (2035-2050) (Sections 3.2-3.6). Compared to the first methodology developed by the authors for the spatially-resolved assessment of risk in the Adriatic basin (Furlan et al., 2018), the focus of this paper is on the innovative procedure applied for the evaluation of synergies between pressures, as well as on the assessment of potential variations of the CI-Index due to climate change scenarios.

\subsection{Conceptual framework}

The CI-Index is based on a conceptual framework allowing to identify main climate and land/sea-based drivers, and to highlight pathways 
Table 1

Main pressures, drivers and metrics representing the selected hazards (hazards definitions are adapted from Patrício et al. (2014) and Furlan et al. (2018)).

\begin{tabular}{|c|c|c|c|}
\hline Hazards & Pressures & Drivers & Metrics \\
\hline $\begin{array}{l}\text { Anthropogenic } \\
\text { introduced } \\
\text { technological hazard }\end{array}$ & $\begin{array}{l}\text { Smothering and } \\
\text { sealing of the seabed }\end{array}$ & $\begin{array}{l}\text { Benthic infrastructures such } \\
\text { as: platforms and wells for } \\
\text { hydrocarbons' extraction, } \\
\text { regasification terminals, } \\
\text { coastal artificial protections, } \\
\text { ports and harbors } \\
\text { infrastructures, cables and } \\
\text { pipelines, areas for unexploded } \\
\text { ordinances', sinking, area of } \\
\text { military practice, wrecks }\end{array}$ & $\begin{array}{l}\text { Presence/absence of benthic } \\
\text { anthropogenic infrastructures located on } \\
\text { the seabed }\end{array}$ \\
\hline \multirow{2}{*}{$\begin{array}{l}\text { Anthropogenic } \\
\text { extractive } \\
\text { technological hazard }\end{array}$} & \multirow{2}{*}{$\begin{array}{l}\text { Abrasion and } \\
\text { extraction of seabed }\end{array}$} & Trawling fishing activities & $\begin{array}{l}\text { Trawling fishing efforts expressed in } \\
\text { hours of fishing activities }\end{array}$ \\
\hline & & $\begin{array}{l}\text { Dredging and resources' } \\
\text { extraction activities }\end{array}$ & $\begin{array}{l}\text { Intensity of dredging activities, } \\
\text { expressed in } \mathrm{m}^{3} \text { of dredged material }\end{array}$ \\
\hline \multirow{2}{*}{$\begin{array}{l}\text { Anthropogenic } \\
\text { physical hazard by } \\
\text { underwater noise }\end{array}$} & \multirow{2}{*}{ Underwater noise } & Maritime traffic & Intensity of shipping traffic \\
\hline & & Platforms and wells & Activity of hydrocarbons' extraction \\
\hline \multirow{4}{*}{$\begin{array}{l}\text { Anthropogenic } \\
\text { biohazard }\end{array}$} & \multirow{4}{*}{$\begin{array}{l}\text { Introduction of non- } \\
\text { indigenous species }\end{array}$} & Maritime traffic & Intensity of shipping traffic \\
\hline & & Ports and harbours activities & $\begin{array}{l}\text { Intensity of ports activity based on the } \\
\text { transport of goods, expressed in } \\
\text { thousand tons per year }\end{array}$ \\
\hline & & Aquacultures & $\begin{array}{l}\text { Presence/absence of aquacultures } \\
\text { including fish and mussel farms }\end{array}$ \\
\hline & & Temperature regime variation & $\begin{array}{l}\text { Number of unusually sea surface warm } \\
\text { events }\end{array}$ \\
\hline \multirow{2}{*}{$\begin{array}{l}\text { Anthropogenic } \\
\text { chronic chemical } \\
\text { hazard }\end{array}$} & \multirow{2}{*}{$\begin{array}{l}\text { Inputs of organic } \\
\text { matter }\end{array}$} & $\begin{array}{l}\text { Nutrient input by rivers } \\
\text { discharge and urban waste } \\
\text { water }\end{array}$ & $\begin{array}{l}\text { Variation in sea surface Chlorophyll 'a' } \\
\text { concentration (Chl 'a') }\end{array}$ \\
\hline & & Temperature regime variation & $\begin{array}{l}\text { Number of unusually sea surface warm } \\
\text { events }\end{array}$ \\
\hline \multirow{2}{*}{$\begin{array}{l}\text { Anthropogenic acute } \\
\text { chemical hazard }\end{array}$} & \multirow{2}{*}{$\begin{array}{l}\text { Introduction of } \\
\text { hazardous substances } \\
\text { by oil-spills }\end{array}$} & $\begin{array}{l}\text { Maritime accidents leading to } \\
\text { oil-spills }\end{array}$ & $\begin{array}{l}\text { Occurrence of ship accidents resulting in } \\
\text { oil spills }\end{array}$ \\
\hline & & Temperature regime variation & $\begin{array}{l}\text { Number of unusually sea surface warm } \\
\text { events }\end{array}$ \\
\hline
\end{tabular}

of interaction between natural and anthropogenic pressures affecting sensitive receptors located in both seabed and water column (e.g. seagrasses, marine protected areas, aquacultures) (Fig. 2).

The conceptual framework was developed based on the DPSIR approach (EEA, 1999; Borja et al., 2016; Patrício et al., 2016) and defines a chain of causal links starting with the 'driving forces' (D), representing natural and anthropogenic stressors which can lead to variations in the state of the environment and/or human systems. It is then assumed that Driving forces, in turn, may exert intentionally or unintentionally exogenic or endogenic (i.e. site-specific human activities carried out within an area) 'pressures' (P) on the environment. Pressures can change among geographic regions, spatial and temporal scales, leading to variation in the 'states' (S) of exposed systems. Finally, these changes can cause multiple types of 'impacts' (I) (e.g. biological, chemical, physical) on the environment, human health and socio-economic activities, eventually leading to 'responses' ( $R$ ) (Kristensen, 2004). As shown in Fig. 2, the framework was designed starting from the 8 impacts' categories (e.g. biological disturbance, physical damage, interference with hydrological processes) and related pressures listed in the Annex 3, Table 2 of the MSFD (EC, 2008). Moreover, drivers linked to each pressure were identified based on the Italian Initial Assessment Reports of the marine environmental state, pointing out, for almost all pressures included in the MSFD, their main stressors as well as a list of indicators and metrics for their evaluation in the Italian marine assessment areas (ISPRA, 2012a, 2012b, 2012c).

\subsection{Methodological steps for the CI-Index implementation}

The conceptual framework approach underpinning the CI-Index (Fig. 2), is operatively translated into five methodological phases: multi-hazard, exposure, vulnerability, risk and cumulative impacts assessment, as depicted in Fig. 3.

Compared to traditional regional risk assessment approaches (Ronco et al., 2015; Torresan et al., 2016; Sperotto et al., 2016) and to the recent study proposed by Furlan et al. (2018), the methodology for the calculation of the CI-Index applies advanced MCDA functions (Demirel et al., 2018; Gain and Giupponi, 2015; Giupponi et al., 2013; Zabeo et al., 2010; Grabisch and Roubens, 2000) for modelling the potential synergies between endogenic and exogenic pressures affecting the marine environment.

Specifically, by integrating metrics and projections of climate, ocean, bio-geochemical and anthropogenic pressures (e.g. temperature variation, bottom stress by abrasion and sealing, oil-spill) the multi-hazard interactions assessment allows the analysis of the interactive effects of multiple pressures acting on the same spatial unit (e.g. interactive sea surface temperature, shipping traffic, ports activities, aquaculture contributing together to biological hazard) (Crain et al., 2008; Brown et al., 2014), under a reference 2000-2015 and future climate change scenario 2035-2050. Then, the exposure assessment identifies and localizes key receptors that could be subject to potential losses in marine areas (e.g. seagrasses and coral and maërl beds). Whereas, the vulnerability assessment phase, focuses on the evaluation of the degree to 


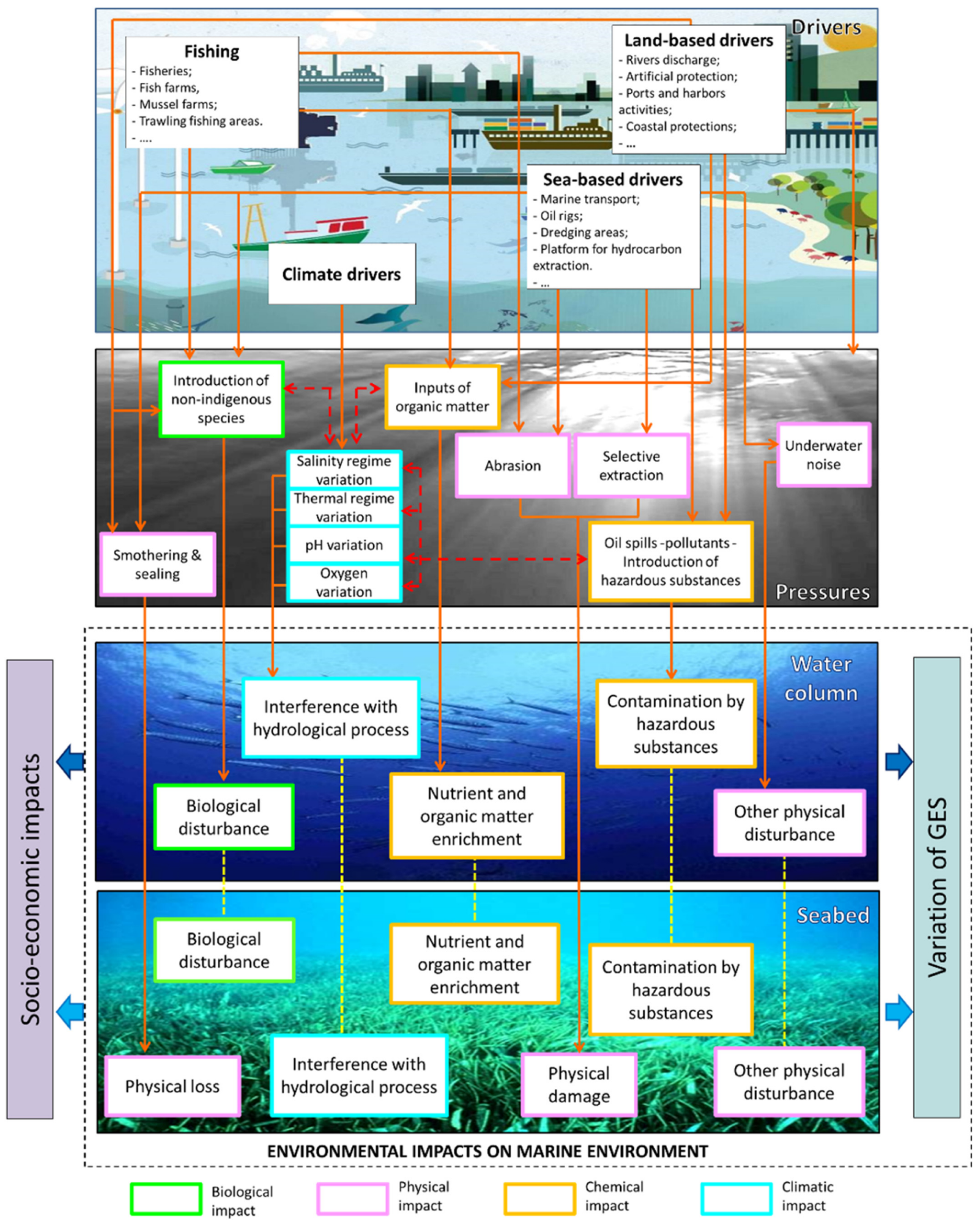

Fig. 2. DPSIR-based conceptual framework highlighting potential pathways of interaction between selected drivers, pressures and impacts. 


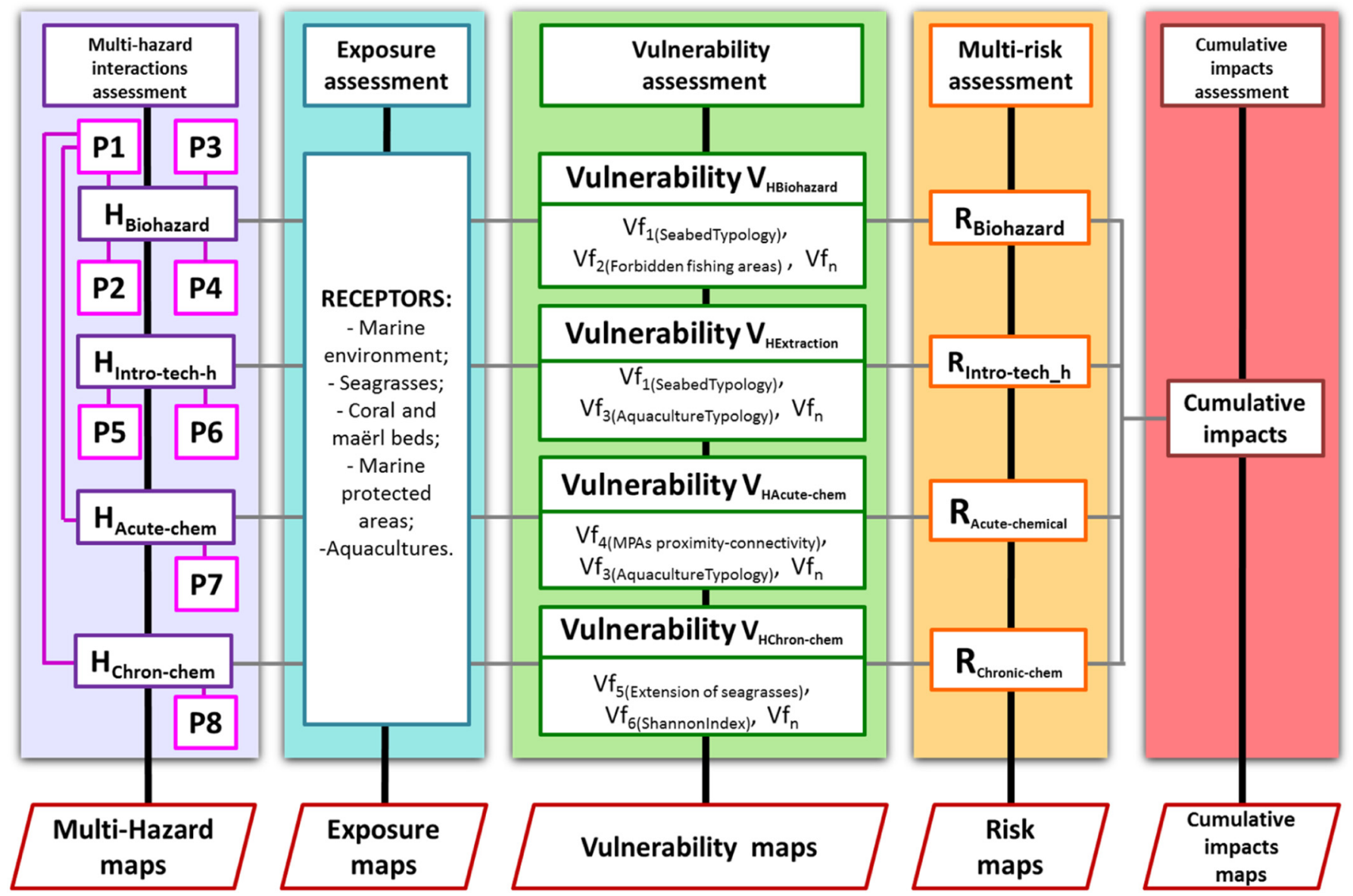

Fig. 3. CI-Index conceptual framework for the evaluation of cumulative environmental impacts on marine areas.

which these receptors could be adversely affected by multiple types of hazards, according to their physical and environmental features (e.g. habitat extent and typology, biodiversity indices). The third risk assessment phase aggregates the information about all the considered hazards (either individual or interactive), with exposure and vulnerabilities, into individual risk layers related to considered stressors. Finally, the conclusive step (cumulative impacts assessment), integrates all the analyzed risks into a synthetic metric (the CIIndex) providing an overall picture of areas more prone to be affected by cumulative environmental impacts.

\subsection{Multi-hazard interactions assessment}

The multi-hazard interactions assessment allows the aggregation of metrics and scenarios of climate, ocean, bio-geochemical and anthropogenic pressures acting on the same marine region.

Compared to traditional regional risk assessment approaches addressing individual risk indicators separately (Furlan et al., 2018; Rizzi et al., 2015; Torresan et al., 2012), the novel procedure implemented for the calculation of the CI-Index allows to consider the interactive behaviors between pressures, applying the Choquet integral (Choquet, 1954; Murofushi and Sugeno, 1989; Grabisch, 1996; Zabeo et al., 2010; Giupponi et al., 2013) to mimic non-linear behavior naturally occurring in dynamic marine systems. As described in the following paragraphs, the multi-hazard interactions assessment phase follows a tiered approach that, starting from the procedure proposed in Furlan et al. (2018) for spatial modelling of distribution and intensity of individual pressures (summarized in Section 2.2) allows for a more advanced analysis of interactive pressures and multi-hazard interactions scenarios in the marine environment (Sections 3.3.1 and 3.3.2).

\subsubsection{Spatial modelling of pressures}

The modelling of pressures has followed specific procedures (Andersen et al., 2013; Micheli et al., 2013; Kappel et al., 2012; Korpinen et al., 2012; Ban et al., 2010; Halpern et al., 2008), able to detect the spatial distribution and intensity of pressures in marine areas, based on available data in both the considered scenarios (reference 2000-2015 and future 2035-2050). In order to maintain the highest spatial resolution and fit to the requirements of the Italian Initial Assessment Reports (ISPRA, 2012b, 2012c), the modelling of pressures and hazard interactions was based on spatial units (i.e. grid cell) of $100 \mathrm{~m}$. While methodologies applied to spatially model each individual pressure have been already introduced in Furlan et al. (2018), the next paragraphs focus on the algorithms and the procedure used to model the multi-hazard interactions scenarios.

\subsubsection{Modelling and normalization of interactive pressures}

Starting from the analysis and spatial modelling of individual pressures already developed in Furlan et al., 2018, the CI-Index adopts advanced MCDA aggregation functions (Malczewski, 1999; Giove et al., 2009) to achieve an estimation of the potential synergic and cumulative effects among multiple interactive pressures.

Specifically, while for the physical hazards $H_{p}$ (i.e. anthropogenic extractive technological hazard, anthropogenic physical hazard by underwater noise), the methodological approach complies with Furlan et al. (2018) and adopts a simplified additive MCDA model to integrate all pressures contributing to the same hazard (methodologies and integration functions are specified in the Supplementary material SM1); for the anthropogenic biohazard, the chronic and acute chemical hazards, we applied the Choquet integral $H_{\mu}(f)$ to model interactive behaviors 
between pressures at stake (e.g. interactive pressures among shipping traffic, ports and aquacultures activities and SST variation leading together to biological hazard). Specifically, by the use of a mapping between criteria, values and scores established by environmental experts, the Choquet integral allows to mimic non-linear behavior, as well as to supply a complete ordered ranking of the considered alternatives (Choquet, 1954; Murofushi and Sugeno, 1989). Introduced by Choquet in the 1954, it is a discrete fuzzy integral which has found increasing application in the context of environmental assessment and management (Grabisch, 1996; Paoli et al., 2007; Zabeo et al., 2010; Delavar et al., 2015; Giupponi et al., 2013). Generalizing additive operators, such as the ordered weighted average (OWA), or the weighted mean, it perfectly fits in situations where antagonistic and synergic behaviors are present. As a drawback, it requires many more parameters than other simplified MCDA methods, but it can be used to approach several cumbersome problems (Agostini et al., 2012; Pizzol et al., 2011; Zabeo et al., 2011). Indeed, the application of the Choquet integral requires assigning specific weights (i.e. interaction weights) to all combinations that can occur between the interactive pressures considered for each hazard, where the number of coalitions to be evaluated depends on the number of selected parameters. Therefore, the resulting hazard scenario is not represented by a linear function, and experts' knowledge about synergic interactions between pressures is directly embedded in the MCDA integration model. The Choquet integral $\left(\boldsymbol{H}_{\boldsymbol{\mu}}(\boldsymbol{f})\right)$ can be defined as follows (Choquet, 1954):

Let $\boldsymbol{\mu}$ (i.e. interaction weights) be a measure on $\boldsymbol{X}$ (i.e. considered interactive pressures for each hazard), whose elements are denoted $\boldsymbol{x}_{\mathbf{1}}, \ldots$ , $\boldsymbol{x}_{\mathbf{2}}$ here (i.e. intensity of interactive pressures). The discrete Choquet integral of a function $\boldsymbol{f}: \boldsymbol{X} \rightarrow \mathbb{R}^{+}$with respect to $\boldsymbol{\mu}$ is defined by:

$$
\boldsymbol{H}_{\boldsymbol{\mu}}(\boldsymbol{f}):=\sum_{i=1}^{\boldsymbol{n}}\left(\boldsymbol{f}\left(\boldsymbol{x}_{(i)}\right)-\boldsymbol{f}\left(\boldsymbol{x}_{(i-1)}\right)\right) \boldsymbol{\mu}\left(\boldsymbol{A}_{(i)}\right)
$$

where:

$\cdot(\boldsymbol{i})=$ indicates that indices have been permuted so that $\mathbf{0} \leq \boldsymbol{f}\left(\boldsymbol{x}_{(\mathbf{1})}\right) \leq$ $\cdots \leq \boldsymbol{f}\left(\boldsymbol{x}_{(\boldsymbol{n})}\right), \boldsymbol{A}_{(\boldsymbol{i})}=\left\{\boldsymbol{x}_{(i)}, \ldots, \boldsymbol{x}_{(\boldsymbol{n})}\right\}$, and $\boldsymbol{f}\left(\boldsymbol{x}_{(\mathbf{0})}\right)=\mathbf{0}$.

In the proposed case the $\boldsymbol{f}$ function is set to be the identity function such that $\boldsymbol{f}(\boldsymbol{x})=\boldsymbol{x}$, therefore results of the application of the Choquet integral directly relates to the measure $\boldsymbol{\mu}$ (interaction weights) and values in $\boldsymbol{X}$ (intensities of the interactive pressures).

As far as the Adriatic Sea is concerned, to set interaction weights for all pressures' coalitions, a questionnaire was prepared and provided to 6 European experts covering multifaceted fields of environmental/marine sciences and chemistry, risk assessment, ecological and physical modelling and maritime spatial planning and management. This questionnaire (reported in the Supplementary material SM2), after a short description of the issue of concern and the case study area, provides one table to be filled in for each analyzed hazard (i.e. anthropogenic biohazard and chronic and acute chemical hazards), representing all the potential combinations between pressures. The Supplementary material SM3 shows an example of tables included in the questionnaire, providing all the coalition scenarios for the biological hazard. In every table, experts are called to assign an interaction weight in the $[0,100]$ closed set to a certain scenario, identified by combinations of interactive pressures for the hazard to be investigated. Each pressure is classified in the 0 -1 range (based on the normalization functions applied for spatial modelling pressures, where 1 stands for the presence of pressure in its maximum value within its ranging classes (i.e. maximum influence in the hazard estimate) and 0 , instead, for its presence at the minimum value (i.e. minimum influence)). As a consequence, the assigned interaction weight, for each pressures' combination, represents the hazard level of the analyzed scenario, where 0 should be interpreted as the hazard null and 100 the maximum one.
In order to better fill in the questionnaire, the three following axioms were provided to experts, explaining the basics concepts of the Choquet integral:

- 0: an empty set has no importance (0).

- 1: the maximum set has the higher importance (100).

- A new added criterion cannot make the importance of a coalition decreases. For instance, if the expert assigns a score equal to 20 to the coalition 1-0-0, then the combination 1-1-0 can assume only values higher than 20.

The first and the second conditions are intuitive border conditions, while the third one is a monotonicity constraint that intuitively states that when more criteria are satisfied (concurring pressures), the global satisfaction cannot decrease (Choquet, 1954).

The resulting output from the collected questionnaire are shown in the three tables reported in the Supplementary material SM4, summarizing the interaction weights provided by the involved experts for all the coalition scenarios between pressures, against the three analyzed hazards. Weights defined by experts were aggregated by calculating the average values between responses provided for all the combinations, in order to get a final measure (i.e. interaction weight) to be implemented in the multi-hazard interactions phase through the application of the Choquet integral.

Once all measures to be used for shaping the final hazard scenarios are defined (i.e. normalized intensity of pressures and interaction weights for each pressures' coalitions), the Choquet integral, parameterized based on these measures, can be applied. Within the Adriatic Sea case study, assigned scores to each combinations of interactive pressures (for the related hazard) were mathematically integrated and processed through tailored GIS-tools (Zabeo et al., 2011), leading to produce final hazard scenarios, representing the integration of every kind of combination among pressures, as the ones that can naturally occur on the investigated area. The resulting hazard score ranges from 0 to 1 , in which 0 represent cells with hazard null (i.e. there is no interactive pressures), whereas 1 the higher hazard in the analyzed marine basin.

\subsection{Exposure and vulnerability assessment}

The main objective of the exposure assessment phase is to identify, select and localize vulnerable marine receptors (i.e. elements potentially at risk) and hot-spot areas featured by high environmental and socio-economic value that could be threatened by the analyzed hazards and, as a consequence, exposed to cumulative impacts in potentially affected marine areas. More specifically, this step focuses on the identification of relevant receptors (i.e. $r 1, r 2, r 3, \ldots, r n$ ) to be considered at the case study level and for the time window of concern; they can be selected based on the main purpose of the assessment, the spatial scale of the analysis and the available data.

Based on already established methodologies in scientific literature for regional scale comparative assessment (Torresan et al., 2012; Rizzi et al., 2015, 2017; Sperotto et al., 2016), the exposure score $E_{j}$ is equal to 0 in the cell where no receptors are placed, whereas 1 where one or more overlapping receptors can be observed. Exposure map with a resolution of $100 \mathrm{~m}$, showing the spatial localization and distribution of all the evaluated targets, is the main output of this assessment step.

Once selected and spatially featured the receptors of the analysis, the following vulnerability assessment phase supports the evaluation of the degree to which targets themselves could be adversely threatened by the considered hazards, according to site-specific physical and environmental information (e.g. species diversity index, seafloor habitat extension and typology, habitat connectivity). The vulnerability assessment proposed in this study, follows the methodological phases described in Furlan et al. (2018), applying the same criteria and functions for vulnerability data selection, classification, scoring and integration. 
Accordingly, the vulnerability assessment phase can be summarized in the following operative steps:

1) Selection of physical (i.e. seabed typology, extension of coral beds and seagrasses meadows) and environmental vulnerability factors (i.e. Shannon biodiversity index, marine protected areas proximityconnectivity, aquaculture typology, forbidden fishing areas), characterizing exposed targets in the case study.

2) Classification and normalization of vulnerability factors in vulnerability classes defined according to expert judgement and literature review (Halpern et al., 2008; Astles et al., 2009; Salomidi et al., 2012; Micheli et al., 2013). As explained in Furlan et al. (2018), almost all the selected vulnerability factors (see Table reported in the Supplementary material SM5) were evaluated as hazardindependent (i.e. associated score doesn't change based on the considered hazard), except for the 'seabed typology' vulnerability factor, which assumes specific scores for each typology of seafloor, according to different hazards (see Table reported in the Supplementary material SM6).

3) Aggregation and normalization of vulnerability factors in a 0-1 range, through the application of the "probabilistic or" function (Kalbfleisch, 1985), returning a single normalized score representing the overall physical and environmental vulnerability for each cell of the case study (i.e. pixel of the raster map) and considered hazard. By applying the "probabilistic or" function, if just a vulnerability factor ( $v f$ ) assumes the maximum value (i.e. 1 ), then the resulting vulnerability score, representing the predisposition of the marine environment to be adversely affected by the considered hazard $\left(V_{h}\right)$, will be equal to 1. On the other side, many vulnerability factors $(v f)$ with low scores contribute together in increasing the final vulnerability score: the more is the number of low vulnerability factor scores, the greater is the final vulnerability.

Resulting vulnerability score ranging from 0 (i.e. no vulnerability) to 1 (i.e. higher vulnerability in the case study area) allow for a relative ranking of more vulnerable areas according to the intrinsic characteristics of the investigated marine region, as well as the final integration of vulnerability estimate in the cumulative impact evaluation.

\subsection{Risk assessment}

The risk assessment phase supports the integration of the information about all the considered hazards (either individual or interactive) with the receptors' exposure and vulnerability, in order to identify and classify areas ad targets that could be at higher risk from each hazard in the investigated area and timeframe (EC, 2008). More specifically, based on the definition proposed by the IPCC (2014), the aggregation of hazard, exposure and vulnerability scores supports the evaluation of risk $\left(R_{h}\right)$, by implementing the following function:

$R_{h}=\left(H_{h}, E_{j}, V_{h}\right)$

where:

$h=$ physical hazard $H_{p}$ or interactive hazards $H_{\mu}(f)$ score calculated for each cell of the case study area and considered timeframe scenarios (i.e. 2000-2015 and 2035-2050);

$R_{h}=$ risk score accounting for the hazard $h$;

$H_{h}=$ hazard score depending on the type of analyzed hazard $(h)$;

$E_{j}=$ exposure score according to the presence/absence of the receptor $j$ in each cell of the case study;

$V_{h}=$ physical and environmental vulnerability score of the investigated cell and related to the hazard of concern $h$ (Section 3.4).

Main output of this step includes an array of 6 risk layers linked to each analyzed hazard (either individual or interactive), identifying and ranking areas and targets that could be mostly affected by multiple endogenic and exogenic risks. As already applied in the previous assessment phases, risk score ranges from 0 to 1 , where 0 represents cells with risk null (i.e. there is no hazard or no physical and environmental vulnerability), whereas 1 the higher risk in the investigated area.

\subsection{Cumulative impact assessment}

The final step of the proposed procedure is the cumulative impact assessment, allowing to integrate all the information produced in the previous steps in the summary CI-Index.

According to the approach developed by Halpern et al. (2008) for the evaluation of cumulative impacts at the global scale, the integration of the estimated risks in the Adriatic Sea case study is based on the following function:

$$
C I=\sum_{i=1}^{m} R_{h}
$$

where:

$C I=$ cumulative impact score calculated for each cell of the case study area and considered timeframe scenarios (i.e. 2000-2015 and 2035-2050);

$m=6$ risk layers from individual and interactive hazards;

$R_{h}=$ normalized risk score (in the $0-1$ range) accounting for the hazard $h$.

The result of this final phase is represented by a summary cumulative impact score (the CI-Index) showing areas and targets potentially affected by cumulative impacts in both the considered timeframe scenarios. In this case, based on the normalized values assumed by risk layers (i.e. from 0 to 1 ), and the applied aggregation function, the resulting cumulative impact score can range from 0 to 6 , in which 0 represent cells where the cumulative impact is null (i.e. there is no overlaid risks in the investigated area), whereas 6 the higher cumulative impact.

\section{Application of the CI-Index in the Adriatic Sea}

The following paragraphs describe, for each operative step of the proposed CI-Index, the output obtained at the case study level (Sections 4.1-4.4), including GIS-based multi-hazard interactions, exposure, vulnerability, risk and cumulative impacts maps and statistics for both reference 2000-2015, and future scenario 2035-2050 under the effect of changing climate conditions. Potential for adaptive maritime spatial planning and climate adaptation in the Adriatic Sea are also addressed.

\subsection{Multi-hazard interactions maps}

Within the multi-hazard assessment phase (Section 3.1) a set of GISbased hazard maps was developed to represent potentially significant hazard scenarios, against which the marine environments and ecosystems need to adapt in order to keep their ecological functions.

Multi-hazard scores range from 0 to 1 and were classified by applying the Equal Interval classification method, allowing the division of scores into 5 equal sized classes (i.e. very low, low, medium, high and very high) (Zald et al., 2006) simplifying maps understanding and comparison between reference and future scenarios. While for the physical hazards (i.e. anthropogenic extractive technological hazard, anthropogenic physical hazard by underwater noise) resulting maps shown the same spatial pattern and hazard intensity presented in Furlan et al. (2018) (Supplementary material SM7 and SM8), for the biological and chemical hazards, synergic effects of multiple pressures acting in concert on the same spatial unit were analyzed. Moreover, it has to be 
underlined that, due to the unavailability of data on future marine planning scenarios (e.g. shipping traffic contributing to underwater noise, trawling fishing to seabed abrasion), maps of physical hazard only focused on the reference scenario 2000-2015. On the other hand, for the biological and chemical hazards (acute and chronic), it was possible to consider the effect of climate change (represented by SST and Chl 'a' variation) in the hazard interactions.

Fig. 4 shows the resulting maps for the acute chemical hazard comparing both temporal scenarios. Higher hazard scores (i.e. ranging from 0.4 to 1 ) are located in the North Adriatic Sea, close to the port of Trieste, where several shipping accidents have been occurred in the 1977-2014 timeframe (IMO/UNEP, 2011; http://accidents.rempec.org/). Compared with the map concerning the chemical hazard by oil-spills showed in Furlan et al. (2018) for the reference scenario 2000-2015, a similar spatial pattern can be recognized. However, wider hazard-prone areas also characterized by a slightly higher score, can be observed in the North Adriatic area, as well as in the Southern Adriatic/Northern Ionian Sea, due to the interactive influence of the SST variation with the potential oil-release, driving to more severe chemical hazards.

Moreover, by looking at the two zooms A and B of Fig. 4, it can be observed that the final hazard score slightly increases in the future scenario 2035-2050 as a consequence of the rising number of unusually warm events calculated in this time window. This pattern reflects the interaction weights assigned by marine experts respect to the pressure related to the oil-spill, recognized as the main driver of the acute chemical hazard in the Adriatic Sea (Section 3.2 and Supplementary material SM3). However, even though the SST increase contributes in a minor extent to drive the overall acute chemical hazard, the environmental impacts associated to this phenomenon cannot be underestimated. As observed by Galli et al. (2017), frequency and severity of marine anomalously warm events is expected to increase in the next decades as a consequence of climate change, with important impacts on marine organisms and ecosystems health. Climate-induced changes has the potential to highly impact the state and dynamics of biological organisms exposing them to environmental conditions that are different from those they are used and adapted to, and potentially outside their tolerance boundaries.

Oil-spill due to shipping accidents represents a relevant threat for the marine environment, since oil contamination may persist for several years after the oil release, and for vulnerable ecosystems, such as salt marshes, environmental impacts may be measurable for decades after the event (Kingston, 2002). Oil release can cause environmental impacts through several processes, including hydrocarbons bioaccumulation in the tissues of marine organisms (Mendelssohn et al., 2012) and the cascading transfer of hydrocarbons up the food chain (Carman et al., 1997).

As far as chronic chemical hazard is concerned, Fig. 5 shows the developed hazard maps where higher score can be detected in both scenarios in the area located around the Po delta river, highly affecting with its nutrient loads trophic levels of the Adriatic Sea (ISPRA, 2012a). Similarly, the hazard map concerning the input of organic matter presented in Furlan et al. (2018), shows that higher hazard scores are highly influenced by the nutrient input by the Po River. As already observed in numerous studies (Barmawidjaja et al., 1995; Druon et al., 2004; Sangiorgi and Donders, 2004), this area appears to be highly vulnerable to seasonal and long-term variations of anthropogenic nutrient load due to the Po River discharges, which impact can be significantly altered by changes in the oceanographic conditions, due to climatic fluctuations (Degobbis et al., 2000). The Po river basin plays a crucial role in the eutrophication processes of the Adriatic Sea, highlighting a relevant land-sea interaction deriving from considerable riverine inputs, able to determine biophysical processes in coastal and offshore areas of the North Adriatic. Human-induced eutrophication highly contributes to reduce water quality and alter ecosystem structure and functions, leading, as cascading effects, to relevant socio-economic implications for key marine sectors grounding their activities on marine environments and resources (e.g. commercial fisheries and seaside tourism) (Sanseverino et al., 2016).

Comparing both scenarios, it is clear how the hazard score increases as result of the rising SST, but, especially in this case, due to the higher

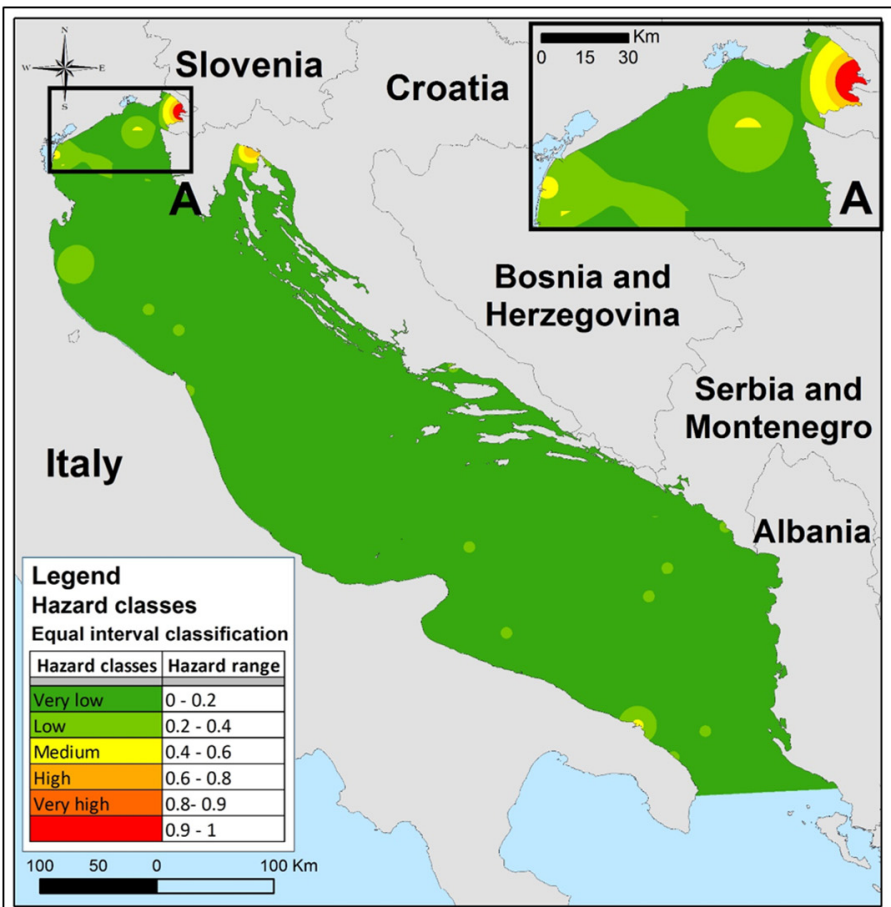

Baseline scenario 2000-2015

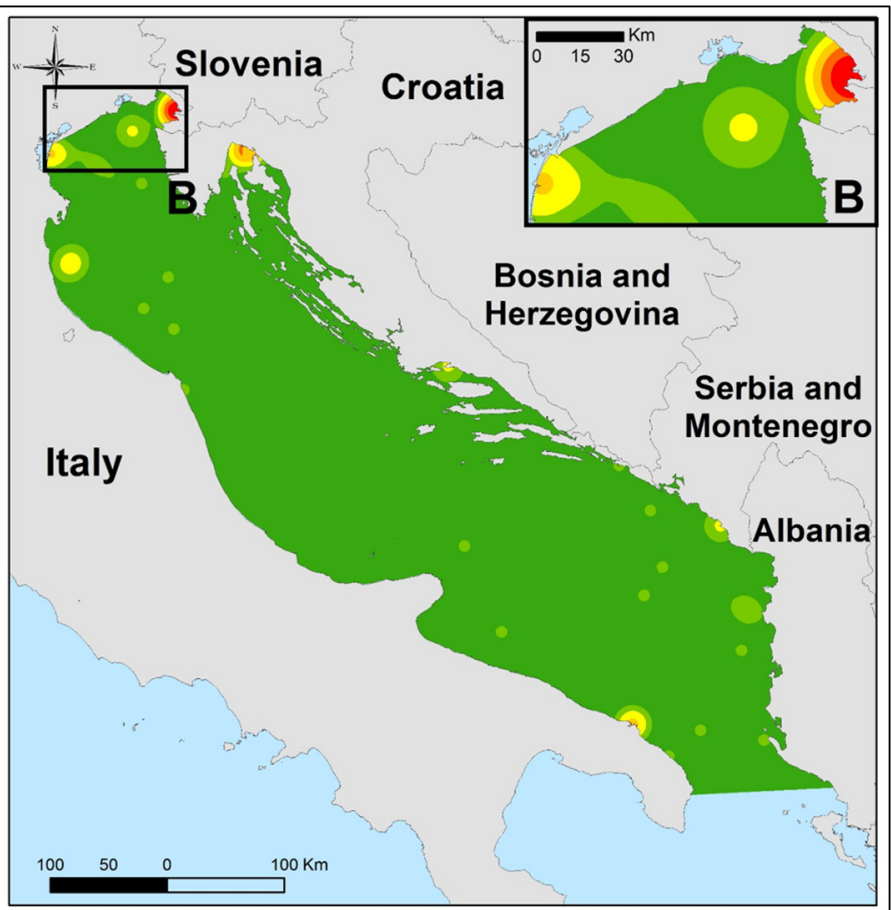

Future scenario 2035-2050

Fig. 4. Hazard maps developed for the Adriatic Sea case study, representing the acute chemical hazard for reference 2000-2015 and future 2035-2050 timeframe scenarios. 


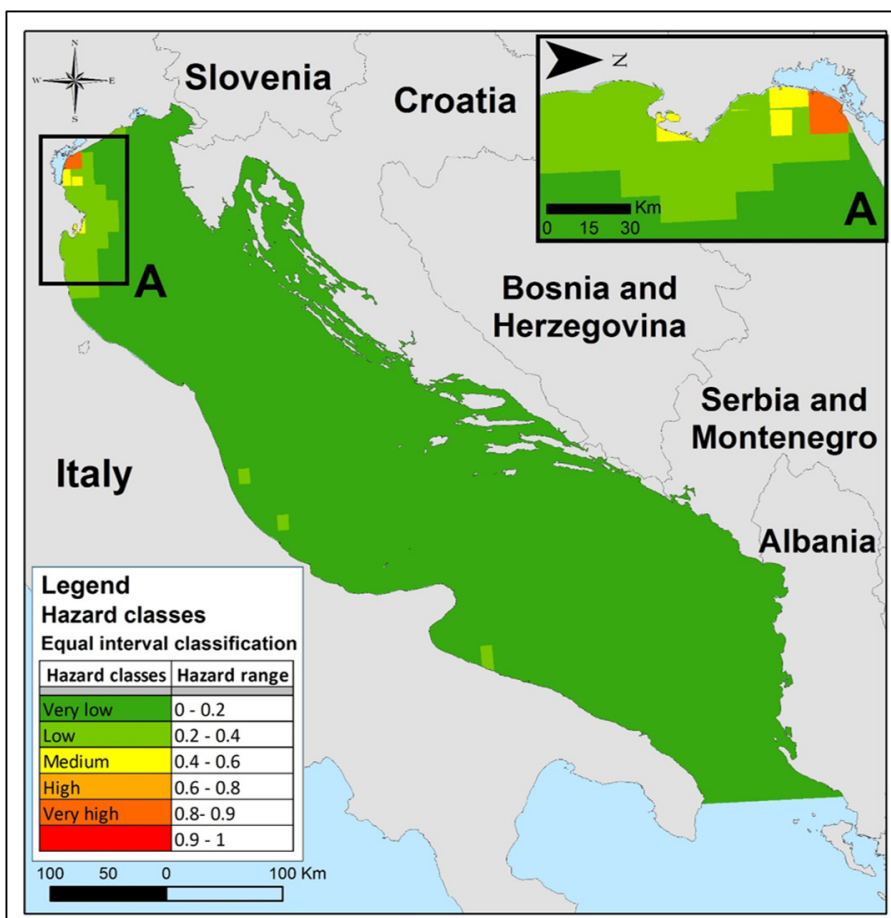

Baseline scenario 2000-2015

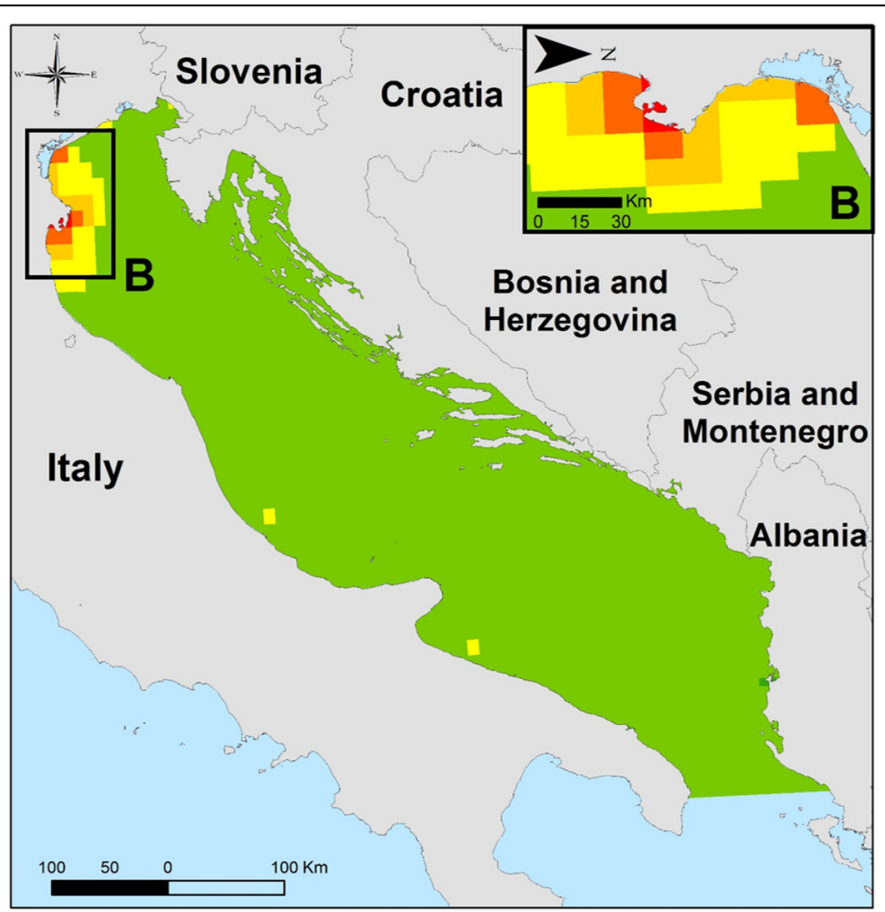

Future scenario $2035-2050$

Fig. 5. Hazard maps developed for the Adriatic Sea case study, representing the chronic chemical hazard for reference 2000-2015 and future 2035-2050 timeframe scenarios.

concentration of chlorophyll 'a', projected for the future scenario 2035-2050.

Finally, by analyzing the resulting maps for the biological hazard (Fig. 6), higher hazard scores (in the range 0-0.4) can be observed, in the reference scenario, close to the most congested shipping routes in the central and southern part of the basin where shipping traffic is more intense. Moreover, high score can be detected as well at the location of the main commercial and touristic ports (i.e. Venice and Trieste in the north Adriatic Sea and Bari and Brindisi in the south) where ballast water discharge by ships daily occur, thus increasing potential introduction of alien species. Comparing these outputs with the hazard map related to the introduction of non-indigenous species showed in Furlan et al. (2018), the same spatial pattern with higher score around the main shipping lanes and harbors, can be detected. In fact, one of

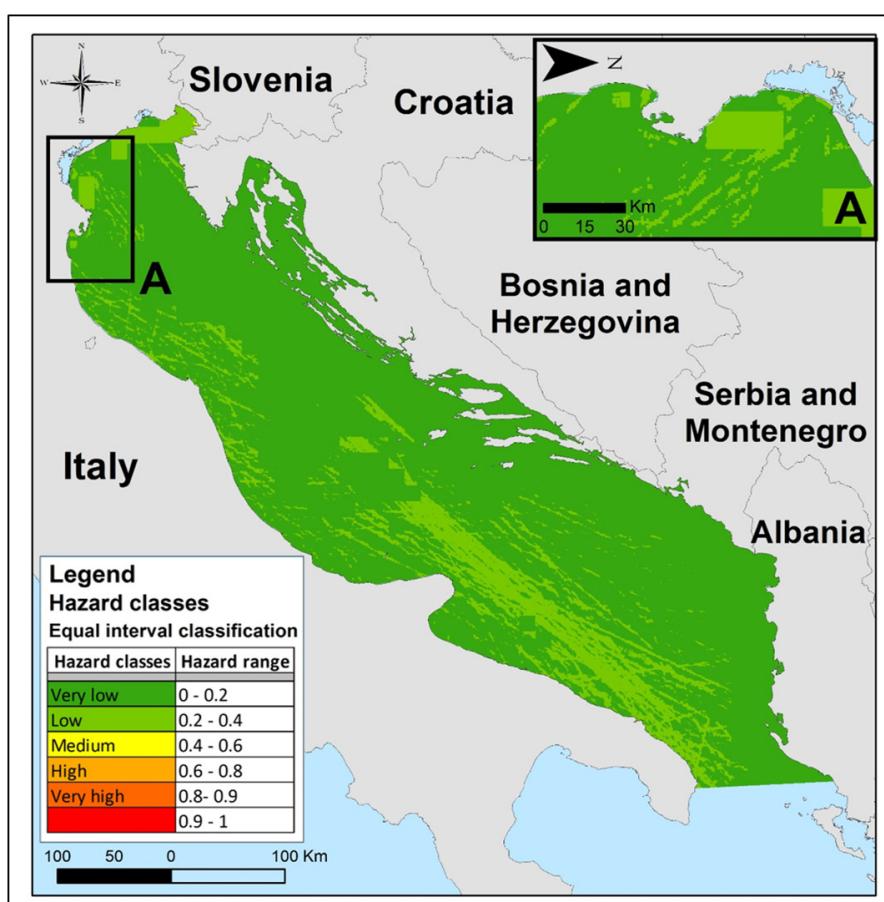

Baseline scenario 2000-2015

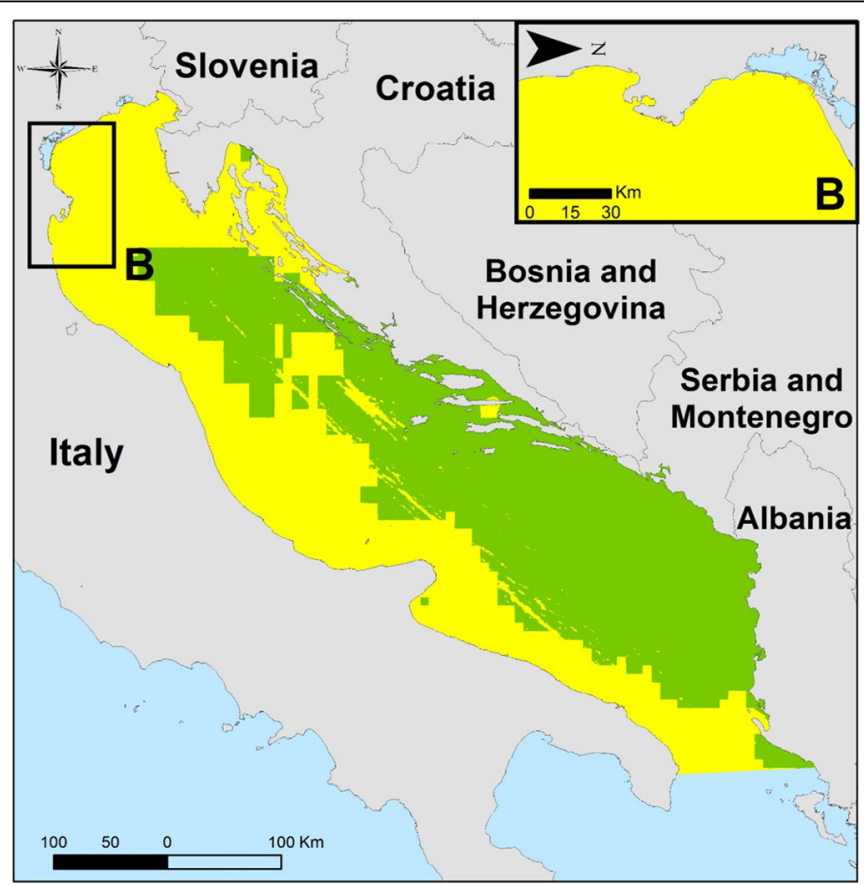

Future scenario 2035-2050

Fig. 6. Hazard maps developed for the Adriatic Sea case study, representing the biological hazard for reference 2000-2015 and future 2035-2050 timeframe scenarios. 
the main vector of marine invasive alien species is the international shipping and ocean-going recreational vessels, offering transport opportunities via hull fouling, sea chests and ballast water and a myriad of other compartments (Bax et al., 2003).

Final biological hazard scores increase in the future scenario 2035-2050 especially in the North Adriatic and along the Italian Exclusive Economic Zone (EEZ), as result of the rising number of unusually warm events calculated in the future scenario (based on methodology explained in Furlan et al., 2018), identified, by involved experts, as the major driver of this hazard (Section 3.3 Supplementary material SM4). Global warming is enabling alien species to expand into regions in which they previously could not survive and reproduce, leading, as cascading effect, to local population losses and extinctions (Breithaupt, 2003). Significant changes are also evident in population dynamics of native species with deep alteration of the geographic ranges, structure and composition of communities (Walther et al., 2009).

By looking at the biological hazard level as a whole, the final scores assume relatively low and moderate values (from 0 to 0.6 ) in both scenarios, never reaching the maximum hazard score equal to 1 . This is due to the combination between the four pressures concurring to the overall biohazard (i.e. SST variation, shipping traffic, port and aquaculture activities), since the coalition in their maximum intensity never occurs in the case study in both timeframes.

However, if alien species will continue to increase as result of the combined effect of climate-related and human-induced pressures, this will have substantial consequences on the marine biodiversity, implicating relevant environmental and economic issues (e.g. extinctions of native species, loss and degradation of habitats and biodiversity, decrease in economic production of activities based on marine environments and resources such as fisheries, aquaculture and tourism) (Bax et al., 2003; Vilà et al., 2010). Accordingly, alongside appropriate climate mitigation measures, commercial and tourist ships should apply effective ballast water management systems, allowing to reduce the hazard of releases of non-indigenous aquatic organisms into the marine environment.

In order to support the cross analysis of results of this phase, for both the analyzed timeframe scenarios and considered physical, chemical and biological hazards, a bar chart comparing the percentage of surface of the case study included in each hazard class was developed (Fig. 7).

The comparative bar chart shows quite low and moderate scores for all considered hazards, with almost all the surface of the case study included in the very low to medium hazard classes (from 0.2 to 0.6 ). Higher hazard scores can be observed for the anthropogenic introduced technological hazard, with about the $5 \%$ of the Adriatic Sea included in the very high hazard class (in the range of $0.8-1$ ), since pressures related to this hazard (i.e. smothering and sealing of seabed) create a severe physical loss of the seabed but in limited areas of the overall case. High and moderate hazard scores can be detected, as well, for the anthropogenic extractive technological hazard (about 65\% of the case study in the range of $0.2-1$ ), due to the intense trawling fishing activities mainly occurring along the Italian coasts (e.g. bottom otter trawl, pair pelagic trawl), highly affecting both biological resources (e.g. extraction of species) and seafloor integrity.

Finally, as already showed in the resulting GIS-based maps, rising hazard scores can be noticed comparing reference and future scenarios, especially for what concern the anthropogenic biohazard, with a shift of hazard values from the lower classes (score ranging from 0 to 0.4 ) to the medium one (from 0.4 to 0.6 ). The same behavior is visible for the anthropogenic chronic chemical hazard, where hazard values, mainly included in the lower classes (about 99\%) within the reference scenario (score ranging from 0 to 0.4 ), completely move to the upper classes with moderate hazard scores (from 0.2 to 0.6 ) if considering the future one.

Hazard maps and indicators represent a valuable support to communicate to policy makers and marine planners about the main source of hazards in the analyzed marine area, as well as about their spatial spreading and intensity. Compared with traditional hazard maps, resulting output of the multi-hazard interactions phase allows to get a screening picture of more complex phenomena, early identifying potential areas shaped by synergic pressures, such as areas where optimal environmental conditions and pathways for non-indigenous species invasion may occur. To this aim they allow, to directly act (and manage) on key drivers mainly contributing to exacerbate a hazard scenario, as well as to avoid spatial conflicts between overlapping activities, putting

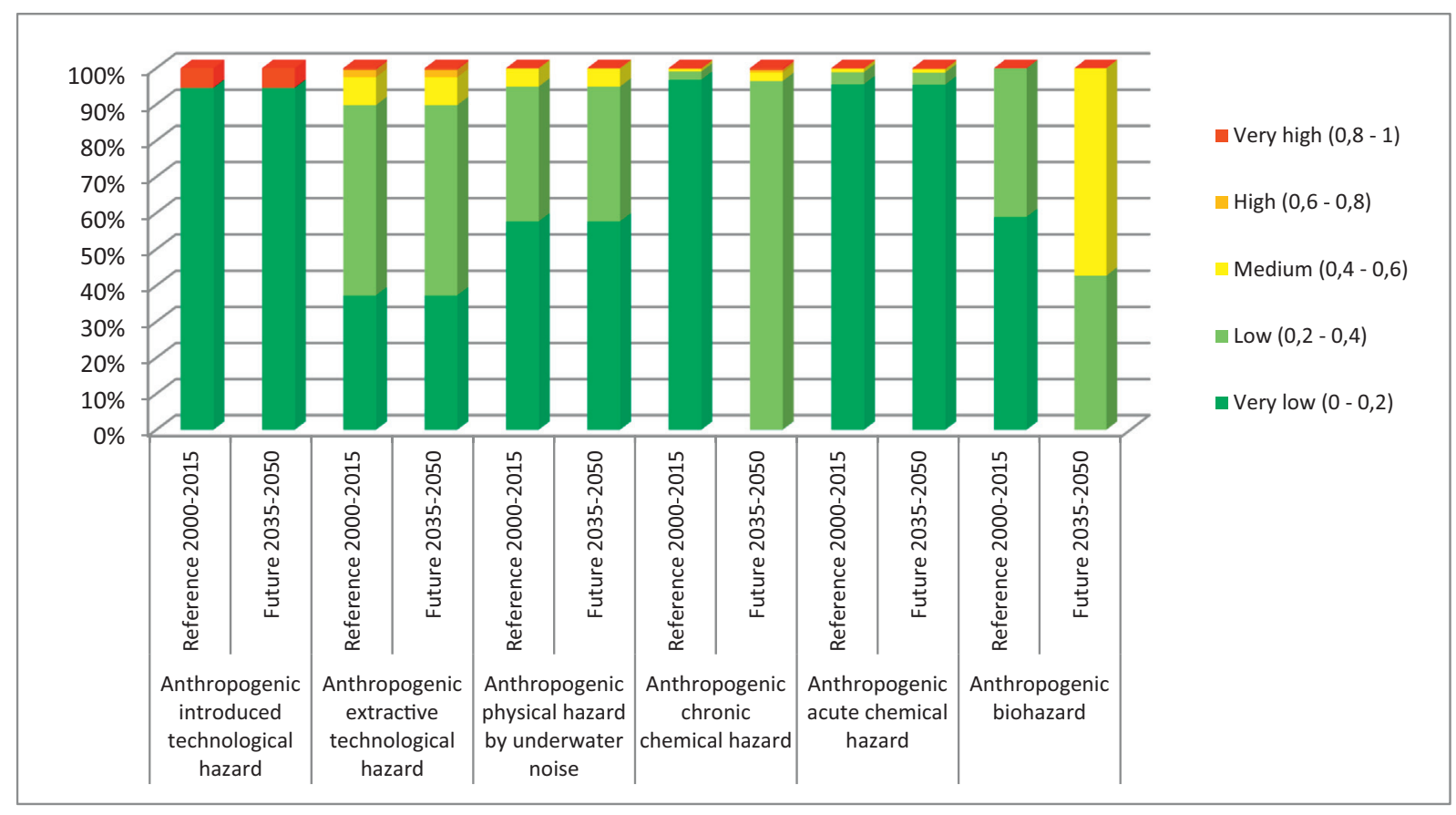

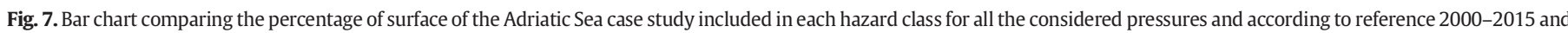
future 2035-2050 scenarios. 
at stake, in a planning perspective, more sustainable and targeted management measures. Finally, by integrating in the evaluation process climate change scenarios (for the anthropogenic acute and chronic chemical hazard and the biological hazard), hazard maps allow to early identify key pressures (and related trend) potentially jeopardizing the marine region of concern in a future timeframe, thus supporting the design and implementation of long-term management plans. In turn, this approach paves the way to go beyond the traditional planning approach, often laying inside the range of recent/current condition, creating a valuable scientific knowledge-base for the design of plans and programmes flexible enough to act (and react) within a wider range of foreseen conditions and able to cope with unexpected events (more adaptive and robust). Finally, with a whole-basin-scale evaluation perspective, the output of the multi-hazard assessment phase, allows to catch and analyze the transboundary nature of pressures, not strictly limited to national marine boundaries. In line with the EUSAIR strategy (www.adriatic-ionian.eu), they represent a valuable support for the design of transnational coordinated actions for the whole marine region, able to face complex environmental issues, as well as challenges of climate change, requiring a broader macro-regional approach to management. In fact, there are many problems affecting the region, such as chemical contamination by oil-spill, eutrophication, and they can only be effectively tackled through the coordination and harmonization of measures, implemented on both point and diffuse sources trough the wider cooperation among countries.

\subsection{Exposure and vulnerability maps}

The exposure map allowed identifying and spatially localizing key marine receptors (i.e. elements at risk) that could be threatened by potential losses and damages due to the considered hazards. Fig. 8 shows the resulting exposure map developed at the case study level by considering as main target the whole marine environment of the Adriatic Sea (light blue boundary), as well as selected hotspots targets: seagrasses meadows (filled green pattern), coral and maërl beds (filled red pattern), marine protected areas (pattern with yellow lines) and aquaculture activities (filled blue pattern).

As far as vulnerability maps are concerned, they support the evaluation of the degree to which receptors could be adversely affected by the considered hazards based on site-specific bio-physical and environmental characteristics (Section 3.2).

Results of this analysis are reported in Table 2, showing that almost all the surface of the analyzed marine environment (always more than $95 \%$ ) is included in the high and very high vulnerability classes (i.e. in the range from 0.6 to 1 ), except for the vulnerability to the anthropogenic introduced technological hazard showing more heterogeneous distribution. This result is in turn reflected on the exposed hotspot targets, since many of them represent the most vulnerable seabed typologies to the considered hazards (e.g. Mediterranean coralligenous communities and sublittoral seagrasses including Cymodocea and Posidonia beds, due to their slow recovery time against physical and chemical pressures), or are located in areas featured by a low biodiversity (according to the Shannon index vulnerability factor) and connectivity linked to the very sparse placement of marine protected areas in the Adriatic basin.

Resulting vulnerability maps and indicators aims at representing the overall vulnerability of the investigated marine region (and related targets) to the considered hazards. Since developed in GIS format, they support the identification of the main factors contributing to increase the vulnerability of a specific area, thus providing marine planners and managers a valuable support to address economic efforts on most suitable strategies to increase resilience of vulnerable targets to the considered hazards. To this aim, effective measures could include different typologies of nature-based solutions and green infrastructures showing cost-effective/cost-competitive alternatives to grey or technology-based measures. Specifically, these actions can comprise
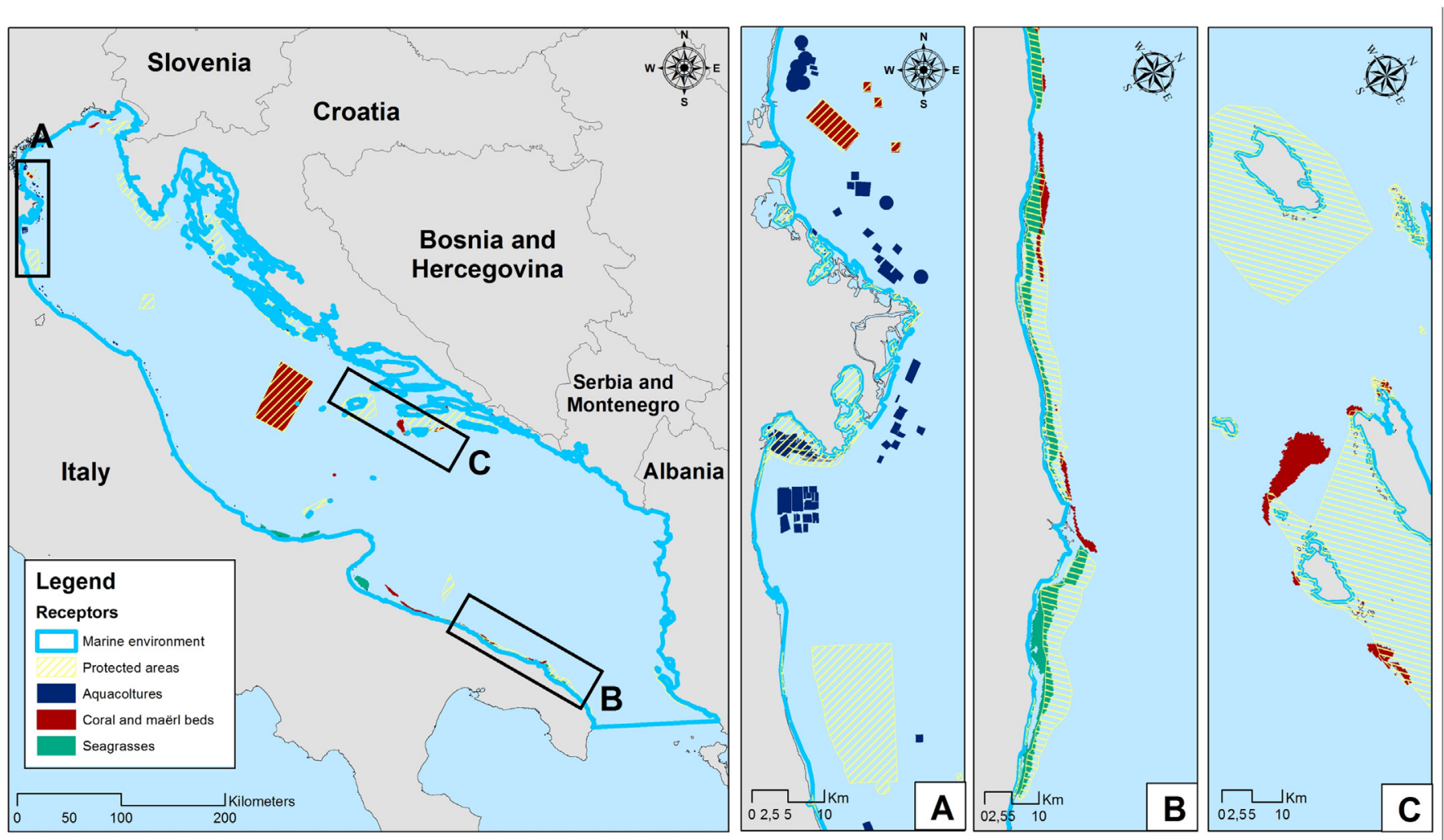

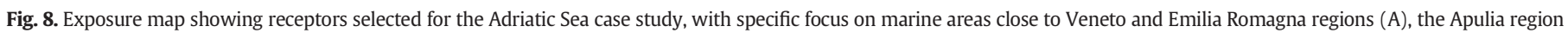
(B) and Croatian coastal areas (C). 
Table 2

Representing the percentage of surface of the Adriatic Sea and selected hotspot targets (i.e. seagrasses, coral and maërl beds, MPAs, aquacultures) included in each vulnerability class.

\begin{tabular}{|c|c|c|c|c|c|c|c|}
\hline & Vulnerability classes & $\begin{array}{c}\text { V @ Anthropogenic } \\
\text { extractive } \\
\text { technological } \\
\text { hazard }\end{array}$ & $\begin{array}{l}\text { V @ Anthropogenic } \\
\text { physical hazard by } \\
\text { underwater noise }\end{array}$ & $\begin{array}{c}\text { V @ Anthropogenic } \\
\text { chronic chemical } \\
\text { hazard }\end{array}$ & $\begin{array}{c}\text { V @ Anthropogenic } \\
\text { acute chemical } \\
\text { hazard }\end{array}$ & $\begin{array}{c}\text { V @ Anthropogenic } \\
\text { biohazard }\end{array}$ & $\begin{array}{c}\text { V @ Anthropogenic } \\
\text { introduced } \\
\text { technological } \\
\text { hazard }\end{array}$ \\
\hline \multirow{5}{*}{$\begin{array}{l}\text { Marine } \\
\text { environment of } \\
\text { the Adriatic Sea }\end{array}$} & Very low $(0-0,2)$ & $0,00 \%$ & $0,00 \%$ & $0,00 \%$ & $0,00 \%$ & $0,00 \%$ & $8,64 \%$ \\
\hline & $\operatorname{Low}(0,2-0,4)$ & $0,00 \%$ & $0,00 \%$ & $0,00 \%$ & $0,00 \%$ & $0,03 \%$ & $23,73 \%$ \\
\hline & Medium $(0,4-0,6)$ & $0,01 \%$ & $0,58 \%$ & $0,00 \%$ & $0,00 \%$ & $4,13 \%$ & $28,29 \%$ \\
\hline & High $(0,6-0,8)$ & $4,61 \%$ & $25,00 \%$ & $1,77 \%$ & $1,76 \%$ & $25,25 \%$ & $22,88 \%$ \\
\hline & Very high $(0,8-1)$ & $95,38 \%$ & $74,42 \%$ & $98,23 \%$ & $98,24 \%$ & $70,59 \%$ & $16,46 \%$ \\
\hline \multirow{5}{*}{ Seagrasses } & Very low $(0-0,2)$ & $0,00 \%$ & $0,00 \%$ & $0,00 \%$ & $0,00 \%$ & $0,00 \%$ & $0,00 \%$ \\
\hline & Low $(0,2-0,4)$ & $0,00 \%$ & $0,00 \%$ & $0,00 \%$ & $0,00 \%$ & $0,00 \%$ & $31,84 \%$ \\
\hline & Medium $(0,4-0,6)$ & $0,00 \%$ & $11,39 \%$ & $0,00 \%$ & $0,00 \%$ & $0,00 \%$ & $22,90 \%$ \\
\hline & $\operatorname{High}(0,6-0,8)$ & $0,01 \%$ & $26,06 \%$ & $0,00 \%$ & $0,00 \%$ & $0,01 \%$ & $30,69 \%$ \\
\hline & Very high $(0,8-1)$ & $99,99 \%$ & $62,55 \%$ & $100,00 \%$ & $100,00 \%$ & $99,99 \%$ & $14,56 \%$ \\
\hline \multirow{5}{*}{$\begin{array}{c}\text { Coral and maërl } \\
\text { beds }\end{array}$} & Very low $(0-0,2)$ & $0,00 \%$ & $0,00 \%$ & $0,00 \%$ & $0,00 \%$ & $0,00 \%$ & $0,00 \%$ \\
\hline & Low $(0,2-0,4)$ & $0,00 \%$ & $0,00 \%$ & $0,00 \%$ & $0,00 \%$ & $0,00 \%$ & $0,17 \%$ \\
\hline & Medium $(0,4-0,6)$ & $0,00 \%$ & $0,50 \%$ & $0,00 \%$ & $0,00 \%$ & $0,00 \%$ & $31,01 \%$ \\
\hline & $\operatorname{High}(0,6-0,8)$ & $9,66 \%$ & $55,07 \%$ & $0,00 \%$ & $0,00 \%$ & $0,00 \%$ & $60,39 \%$ \\
\hline & Very high $(0,8-1)$ & $90,34 \%$ & $44,43 \%$ & $100,00 \%$ & $100,00 \%$ & $100,00 \%$ & $8,42 \%$ \\
\hline \multirow{5}{*}{ Aquaculture } & Very low $(0-0,2)$ & $0,00 \%$ & $0,00 \%$ & $0,00 \%$ & $0,00 \%$ & $0,00 \%$ & $9,24 \%$ \\
\hline & $\operatorname{Low}(0,2-0,4)$ & $0,00 \%$ & $0,00 \%$ & $0,00 \%$ & $0,00 \%$ & $0,00 \%$ & $1,60 \%$ \\
\hline & Medium $(0,4-0,6)$ & $0,77 \%$ & $2,57 \%$ & $0,01 \%$ & $0,00 \%$ & $0,00 \%$ & $4,46 \%$ \\
\hline & $\operatorname{High}(0,6-0,8)$ & $8,16 \%$ & $7,06 \%$ & $6,94 \%$ & $0,00 \%$ & $0,00 \%$ & $9,77 \%$ \\
\hline & Very high $(0,8-1)$ & $91,06 \%$ & $90,36 \%$ & $93,05 \%$ & $100,00 \%$ & $100,00 \%$ & $74,93 \%$ \\
\hline \multirow{5}{*}{$\begin{array}{c}\text { Marine } \\
\text { protected areas }\end{array}$} & Very low $(0-0,2)$ & $0,00 \%$ & $0,00 \%$ & $0,00 \%$ & $0,00 \%$ & $0,00 \%$ & $37,00 \%$ \\
\hline & Low $(0,2-0,4)$ & $0,00 \%$ & $0,00 \%$ & $0,00 \%$ & $0,00 \%$ & $0,03 \%$ & $14,87 \%$ \\
\hline & Medium $(0,4-0,6)$ & $0,15 \%$ & $4,82 \%$ & $0,01 \%$ & $0,01 \%$ & $10,26 \%$ & $18,14 \%$ \\
\hline & High $(0,6-0,8)$ & $17,95 \%$ & $43,82 \%$ & $9,85 \%$ & $9,71 \%$ & $27,63 \%$ & $23,58 \%$ \\
\hline & Very high $(0,8-1)$ & $81,90 \%$ & $51,36 \%$ & $90,14 \%$ & $90,28 \%$ & $62,08 \%$ & $6,41 \%$ \\
\hline
\end{tabular}

the establishment of new MPAs, providing, on one side, different level of protection by allowing or prohibiting within their boundaries a range of human-made activities (thus limiting potential pressures to the marine environment), on the other side, in a well-connected MPAs network, boosting the health of ecosystems, and even turn around the downward trends of marine biodiversity. Moreover, as further measure, the consolidation and restoration of aquatic habitats via transplantation of seagrasses meadows can contribute, as well, to increase resilience of marine habitats by providing valuable regulating ecosystem services playing a key role in climate adaptation (e.g. protection from storms, water regulation, dissipation of wave energy, sediment stabilization) (Ondiviela et al., 2014).

\subsection{Risk maps}

The risk assessment phase supported the development of a set of relative risk maps, one for each selected hazard and considered timeframe scenario. Resulting risk maps present relevant spatial variations across

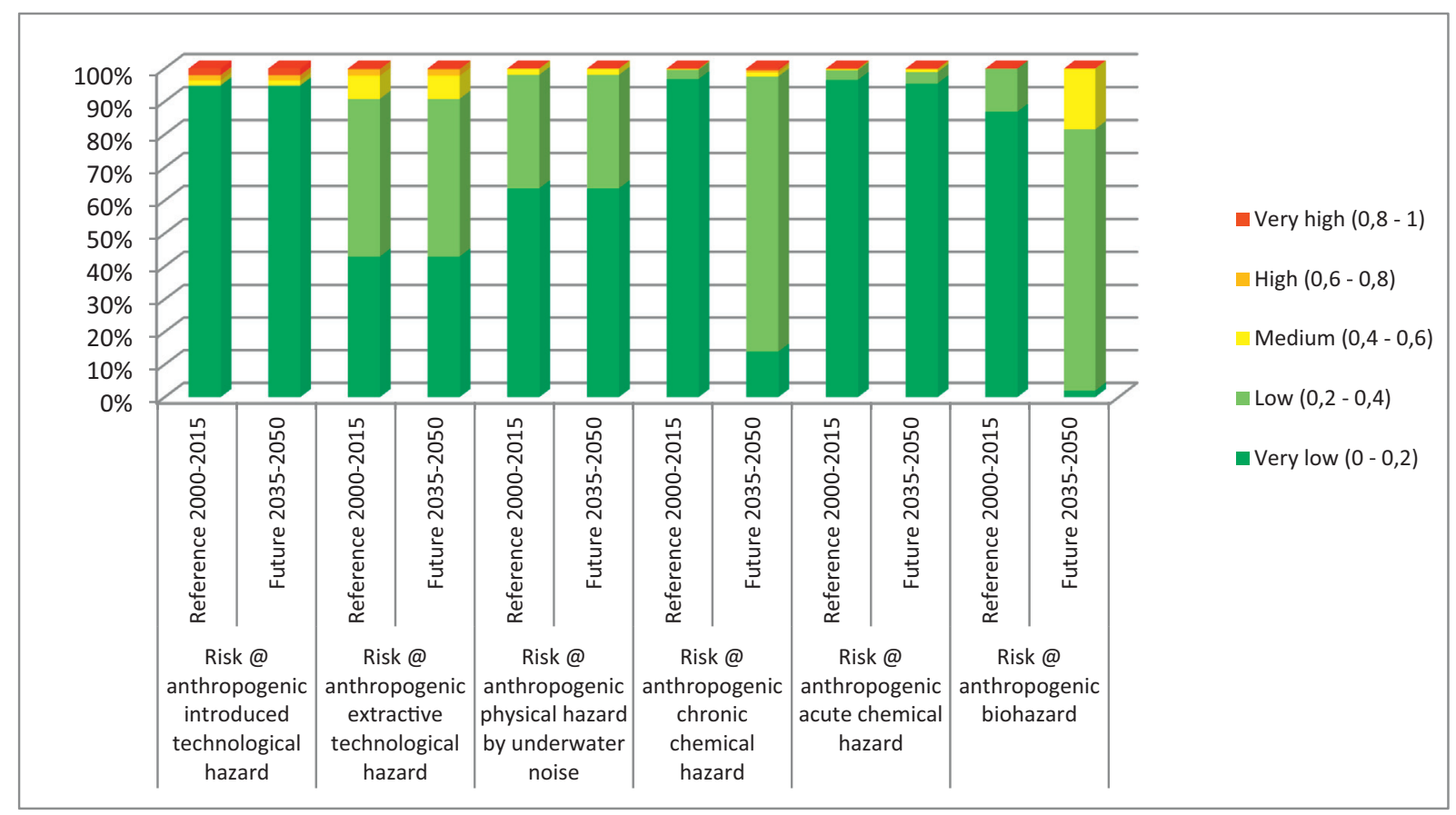

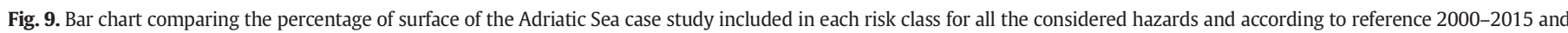
future 2035-2050 scenarios. 
the whole case study based on the spatial pattern of hazards, since vulnerability assumes quite homogeneous values equal to 1 for almost all the considered hazards and in the overall study area. Resulting output for the risk assessment phase are summarized in the bar chart in Fig. 9 representing the percentage of the Adriatic Sea included in each risk class, for both reference and future scenarios (i.e. 2000-2015 and 2035-2050). Specifically, by analyzing it, low and moderate scores for all the considered risks can be observed, with higher values detected for risk to the anthropogenic extractive technological hazard, with more than $50 \%$ of the Adriatic Sea included in the low and moderate risk classes (i.e. score ranging from 0.2 to 0.6 ). The background changes a little bit in the future timeframe scenario (i.e. 2035-2050) where the major risk to the marine environment is represented by the anthropogenic biological hazard, with a shift of risk values from the lower classes (i.e. in the range of $0-0.4$ in the reference scenario) to the upper ones with moderate risk scores (i.e. 0.2-0.6). A similar pattern can be noticed for the risk to the anthropogenic chronic chemical hazard, where risk scores, mostly included in the lower classes within the reference scenario (i.e. score ranging from 0 to 0.4 ), completely move to risk classes with scores in the range from 0.2 to 0.6 .

Based on the equation applied for risk appraisal (Eq. (2), Section 3.5), resulting risk maps support the identification of mayor risks contributing to increase cumulative impacts, thus providing to marine planners and managers a screening risk tool underpinning the development of cross-sectorial risk management plans, aimed at reducing exposure to human-made and natural hazards and increase resilience of marine ecosystems to the identified threats. Moreover, by also evaluating risks induced by land-based drivers (i.e. river discharge leading to nutrient and input), risk maps and indicators can support territorial planning, as well as infrastructural design of new projects aimed at reducing pressures on marine areas and contribute to a more sustainable land-sea interface. Finally, by taking into account a potential future climate change scenario, resulting risk maps also represent a sciencebased knowledge to address the development and implementation of management measures to respond to the rising challenges posed by climate change.

\subsection{Cumulative impacts maps and indicators}

Once implemented the risk assessment phase, resulting risk maps, for both baseline and future scenarios, were integrated based on Eq. (3) (Section 3.6), leading to the development of two cumulative impact maps. Cumulative impact scores range from 0 to 6 based on the number of evaluated endogenic and exogenic risks. In order to better visualize moderate cumulative impacts scores, values in the range from 0 to 2.5 were classified by defining 5 classes equal in size, whereas a unique class with values from 2.5 (higher bound of the previous classes) to the maximum cumulative impact score equal to 6 was set to isolate the higher values (restricted in small areas of the case study). Indeed, as showed in Fig. 10, the resulting cumulative impacts maps, for the reference and future scenarios, show basically low and moderate cumulative impact scores ranging from 0 to 2 . They are mostly focused in the Italian continental shelf due to the massive shipping traffic, the trawling activities taking place seawards from the Italian coast, and the location of benthic infrastructures leading to severe physical impacts on the seabed. More specifically, higher cumulative impacts scores (always within moderate classes) can be detected in the Nord Adriatic Sea in both timeframe scenarios. Highly affected are mainly located around the Po delta river and the ports of Trieste and Venice (Fig. 10A and B) due to the high nutrient input, as well as the intense shipping traffic and ports activities in these areas. The same spatial pattern (focusing on the reference scenario since comparable) can be observed in the cumulative impact map developed at the global scale by Halpern et al. (2008) and Micheli et al. (2013) for the Mediterranean Sea, with higher cumulative impacts score mainly along the Italian continental shelf. Moreover, by moving comparison on analysis performed on the Adriatic Sea, the same cumulative impact behavior can be detected in the study by Depellegrin et al. (2017) with higher cumulative impact scores dominant in the sea areas of Friuli-Venezia Giulia, Veneto and Emilia Romagna Region (i.e. Northern Adriatic).

Moreover, by analyzing maps for the two different timeframe scenarios (Fig. 10), a rising cumulative impact score can be observed.

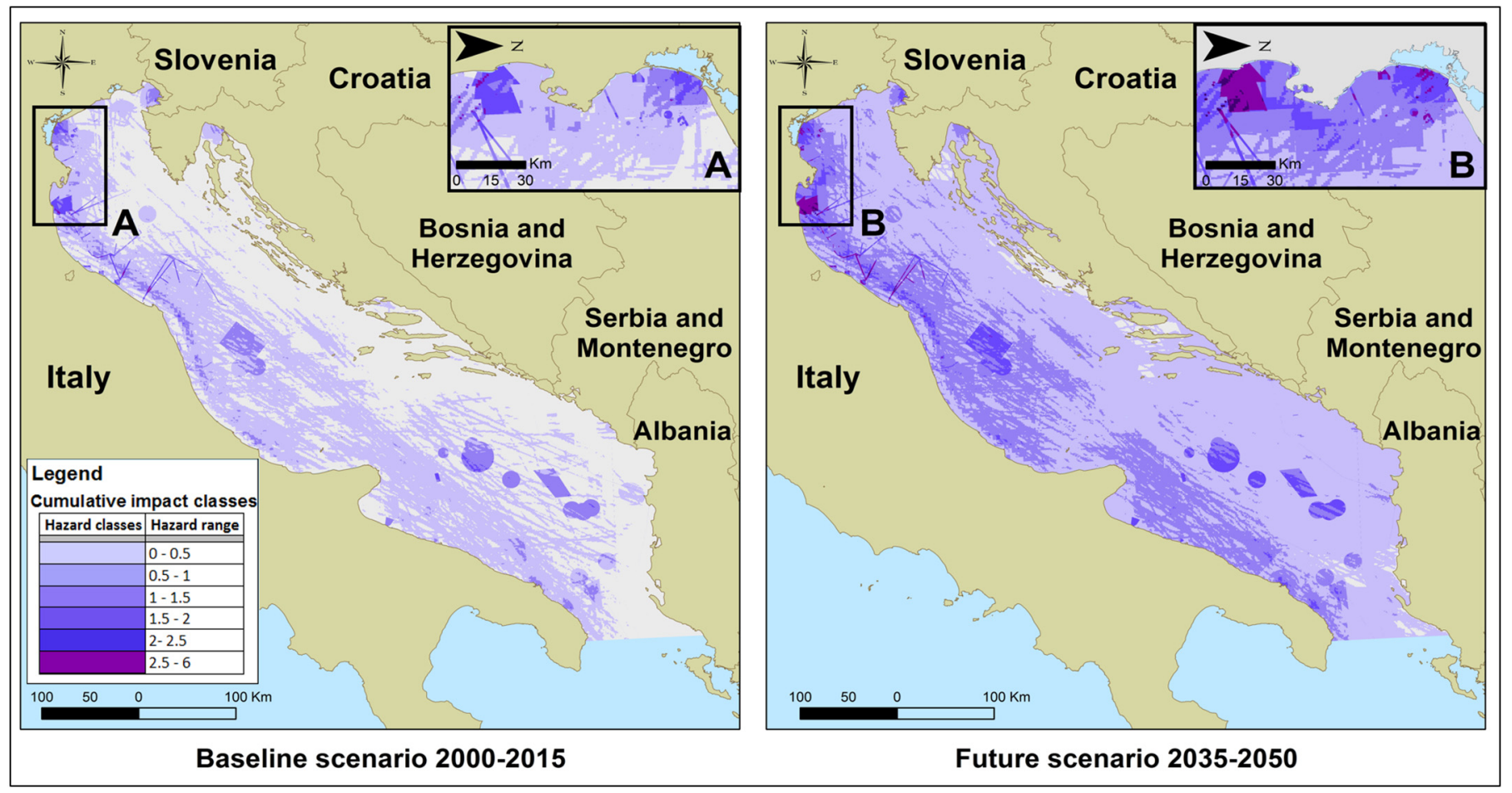

Fig. 10. Cumulative impacts maps developed for the Adriatic Sea case study for the reference (2000-2015) and future (2035-2050) scenarios. 
Indeed, looking at the reference scenario, almost all the surface of the Adriatic Sea is included in the lower classes with scores ranging from 0 to 1 (about 95\%), whereas in the future ones in classes with values extending from 0.5 to 2 (about 99\%). This output is strictly linked to the rising SST that, interacting with the other endogenic pressures (e.g. shipping traffic, ports activities, oil-spill), highly contributes to increase cumulative impacts at the case study level. Finally, by focusing the analysis on exposed targets, Table 3 shows that they could be all adversely affected by cumulative impacts, especially as baseline will move due to climate change, leading to warmer conditions. More specifically, a general shift from the lower class with scores ranging from 0 to 0.5 to the upper ones from 0.5 to 1.5 can be observed for almost all the considered targets (i.e. seagrasses, coral and maërl beds and protected areas). Higher values of cumulative impact, always included in the lower and moderate classes, are assumed by the receptor 'aquacultures' where, in the future scenario $2035-2050$, more than the $25 \%$ of the related surface is included in the class with scores ranging from 1.5 to 2 (Table 3 ). Considering the others receptors, the percentage of surface in the same class is always lower (around the 1-2\%). Moreover, although in small extent (i.e. about the $0.03 \%$ ), in the future scenario part of the surface of the receptor aquaculture is included in the higher cumulative impact class (i.e. scores ranging from 2.5 to 6 ), due to the localization of this target along the coast of the North Adriatic Sea, especially around the Po delta river, where higher cumulative impacts scores were detected both in the reference and future scenarios (Table 3 ). The receptor MPAs in the future scenario also shows a small percentage of its surface (i.e. about the $0.11 \%$ ) included in the higher cumulative impact class, since a wide protected area (i.e. a biological protection zone established under the Italian Ministerial Decree 16/03/2004) is right located in the Southern part of the Po delta river, where cumulative impacts values are higher.

Cumulative impacts maps and statistics depict an overall picture of the marine system at stake thus providing support for integrated and cross-sectorial marine spatial planning and strategic decisionmaking, embracing the sustainable use and protection of marine spaces and resources. Specifically, they represent a valuable tool to aid design and implementation of integrated policies and plans aimed at managing uses of the sea (often in conflict with each other's) and, in turn, reduce endogenic pressures (e.g. limit the shipping traffic on specific areas featured by vulnerable marine habitat) and related human-made impacts. Moreover, by providing information for the reference and future scenario due to climate change, resulting output from this assessment phase can be used to put in place more adaptive plans and policies able to in-itinere accommodate changes induced by exogenic unmanaged pressures, by acting at the effective management scale on causes (need to be addressed locally) and consequences (require global action with mitigation strategies) (Patrício et al., 2014).

\section{Conclusions}

This study proposed an integrated index for the evaluation of cumulative impacts produced by interactive endogenic and exogenic pressures on marine areas and vulnerable targets.

A wide array of multi-hazard, vulnerability, exposure, risk and cumulative impacts maps and metrics were developed for the Adriatic Sea case study, against a reference and future climate scenario (i.e. 2000-2015 and 2035-2050 timeframe). These outputs provide a comprehensive evaluation (and relative ranking) of marine areas and targets that are already threatened and could be, as well, compromised by synergic pressures under the effect of changing climate conditions. These aspects represent a step forward compared to the multi-hazard methodology presented in Furlan et al. (2018), and over traditional approaches developed so far for cumulative impacts appraisal. The novelty of the proposed CI-Index grounds on the multi-hazard interactions assessment phase, supporting, through the application of the Choquet integral, spatial modelling of complex phenomena induced by interactive pressures (e.g. introduction of non-indigenous species). Moreover, even though for a limited number of pressures (i.e. SST variation and nutrient input), the integration of a climate scenario in the assessment process, allowed to account for mid-term environmental changes, unlocking new information useful for the design and implementation of more robust policies able to adapt to changes over time.

Thanks to the modularity of its methodological approach, the CIIndex is flexible to allow for an extension of the evaluated hazards (e.g. oceans' acidification, marine litters, diverse fishing methods), as well as the identification of further (or more detailed) groups of receptors (e.g. marine mammals and fish species, underwater cultural heritage sites) and vulnerability factors (e.g. habitat specificity), as more research on environmental and anthropogenic data will be available. Furthermore, different climate scenarios can be explored, by applying the same methodological approach to assess potential effects under longer timeframes relevant for management aims (e.g. 2070-2100), as well uncertainty linked with climate modelling. Finally, the performed assessment can be easily up-scaled to evaluate consequences of interactive pressures on wider marine region (e.g. Mediterranean scale), as well as down-scaled through the integration of more detailed input data.

The developed approach also presents some limitations mainly linked with the methodological assumptions applied during the assignation of scores in the vulnerability and multi-hazards interactions assessment phases. As far as vulnerability assessment is concerned, more accurate spatial models coupling vulnerability of marine ecosystems to the selected pressures, should be considered for a joint evaluation of their recovery potential and resilience to perturbations. Within the multi-hazard interactions assessment phase, the same issue could be overcome by involving a wider number of marine experts in the

Table 3

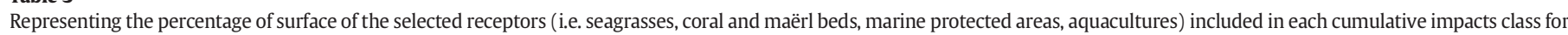
the reference (2000-2015) and future (2035-2050) scenarios.

\begin{tabular}{|c|c|c|c|c|c|c|c|c|}
\cline { 2 - 9 } \multicolumn{1}{c|}{} & \multicolumn{2}{|c|}{ Seagrasses } & \multicolumn{2}{c|}{ Coral and maërl beds } & \multicolumn{2}{c|}{ Aquaculture } & \multicolumn{2}{c|}{ Marine protected areas } \\
\hline $\begin{array}{c}\text { Classes } \\
\begin{array}{c}\text { Cumulative } \\
\text { impact } \\
\text { score }\end{array}\end{array}$ & $\begin{array}{c}\text { Cl baseline } \\
\text { scenario } \\
(2000- \\
2015)\end{array}$ & $\begin{array}{c}\text { Cl future } \\
\text { scenario } \\
(2035- \\
2050)\end{array}$ & $\begin{array}{c}\text { Cl baseline } \\
\text { scenario } \\
(2000-2015)\end{array}$ & $\begin{array}{c}\text { Cl future } \\
\text { scenario } \\
(2035-2050)\end{array}$ & $\begin{array}{c}\text { Cl baseline } \\
\text { scenario } \\
(2000- \\
2015)\end{array}$ & $\begin{array}{c}\text { Cl future } \\
\text { scenario } \\
(2035- \\
2050)\end{array}$ & $\begin{array}{c}\text { Cl baseline } \\
\text { scenario (2000- } \\
2015)\end{array}$ & $\begin{array}{c}\text { Cl future } \\
\text { scenario (2035- } \\
2050)\end{array}$ \\
\hline $\mathbf{0 - \mathbf { 0 . 5 }}$ & $55,30 \%$ & $0,00 \%$ & $42,42 \%$ & $0,00 \%$ & $10,36 \%$ & $0,00 \%$ & $72,66 \%$ & $8,94 \%$ \\
\hline $\mathbf{0 . 5}-\mathbf{1}$ & $41,98 \%$ & $65,97 \%$ & $56,64 \%$ & $54,73 \%$ & $70,11 \%$ & $14,66 \%$ & $24,63 \%$ & $69,59 \%$ \\
\hline $\mathbf{1}-\mathbf{1 . 5}$ & $2,68 \%$ & $31,90 \%$ & $0,92 \%$ & $44,53 \%$ & $13,20 \%$ & $56,67 \%$ & $2,13 \%$ & $19,28 \%$ \\
\hline $\mathbf{1 . 5}-\mathbf{2}$ & $0,03 \%$ & $2,10 \%$ & $0,02 \%$ & $0,74 \%$ & $6,33 \%$ & $25,18 \%$ & $0,53 \%$ & $1,83 \%$ \\
\hline $\mathbf{2 - 2 . 5}$ & $0,00 \%$ & $0,03 \%$ & $0,00 \%$ & $0,01 \%$ & $0,00 \%$ & $3,46 \%$ & $0,06 \%$ & $0,25 \%$ \\
\hline $\mathbf{2 . 5}-\mathbf{6}$ & $0,00 \%$ & $0,00 \%$ & $0,00 \%$ & $0,00 \%$ & $0,00 \%$ & $0,03 \%$ & $0,00 \%$ & $0,11 \%$ \\
\hline
\end{tabular}


assignations of the 'interaction weights' to the coalitions scenarios, thus getting a more robust set of scores. Focusing on technical aspects, a more congruent and detailed basis for the assessment should be prepared, collecting spatial data updated to the same timeframe and presenting a higher spatial resolution able to catch local-scale phenomena. Moreover, advanced spatial models for pressures' characterization, should be implemented for a more realistic representation of marine dynamics. This would be pursued through the integration of data and functionalities from hydrodynamic models (also in 3D dimensions), allowing to feature marine circulation processes exerting relevant impacts on natural processes and marine life (e.g. larval dispersal/transport, distribution patterns of organism and their patchiness), as well as pressures spreading in the water column. Finally, to make results even more useful to inform maritime spatial planning processes, future development scenarios for touristic and commercial shipping routes, new port implementation and extensions, localization of offshore infrastructures (including their potential pressures on the marine environment) should be considered in the CI-Index application.

The development of the CI-Index is part of a more complex tiered approach, which starts from spatial modelling of individual pressures (presented in Furlan et al., 2018) to then focuses on the evaluation of cumulative impacts induced by interactive pressures and, finally, move to scenario analysis through the application of Bayesian Networks techniques. In fact, further challenging improvement of the proposed CIIndex will consider dynamic patterns of marine ecosystems, evaluating cascading effects on both hazards and vulnerabilities against space and time dimensions. This will be pursued through the design and application of more-sophisticated analytical frameworks, able to integrate complex system concepts and methods (e.g. GIS-based Bayesian Networks). It would result in a dynamic tool for multi-scenarios analysis, allowing to explore when, where and how operate to achieve desired management outcomes and specific environmental targets. Moreover, as further endpoint of the proposed assessment process, cumulative impacts over ecosystem services provision should be considered to identify marine areas where management actions would be best targeted to avoid losses and damages on key habitat playing a crucial role in marine life. Finally, since data in the marine domain is growing at an unprecedented rate, especially when considering the terabytes of oceanographic dataset released by numerical models, as well as heterogeneous information obtained from multiple sources and sensors to monitor environmental status (e.g. satellite observations), potential of big data analytics should be also exploited in environmental impacts appraisal. This would allow simplifying and operationalizing time-consuming data pre-processing and integration phases, creating an analytical functional chain able to automatize cumulative impact assessment and multi-scenarios analysis under different input data and constraints.

\section{Acknowledgment}

The research leading to these results has been partly funded by the PERSEUS project (Policy-oriented marine Environmental Research for the Southern European Seas, http://www.perseus-net.eu) within the European Union 7th Framework Programme - theme "Oceans of Tomorrow" (Grant Agreement No. 287600). Additional fundings were provided in the frame of the Strategic Projects of the Foundation Centro Euro-Mediterraneo sui Cambiamenti Climatici. The authors gratefully acknowledge their colleagues Dr. Alex Zabeo and Dr. Lisa Pizzol for their valuable advices and suggestions during the application of the Choquet integral and the master student Giulia Donadello, of the Ca' Foscari University of Venice (http://www.unive.it), for her contribution in the GIS data collection and pre-processing.

\section{Appendix A. Supplementary data}

Supplementary data to this article can be found online at https://doi. org/10.1016/j.scitotenv.2019.03.021.

\section{References}

Agostini, P., Pizzol, L., Critto, A., D'Alessandro, M., Zabeo, A., Marcomini, A., 2012. Regional risk assessment for contaminated sites part 3: spatial decision support system. Environ. Int. 48, 121-132.

Andersen, J., Stock, A., Heinänen, S., Mannerla, M., Vinther, M., 2013. Human Uses, Pressures and Impacts in the Eastern North Sea. Aarhus University, DCE-Danish Centre for Environment and Energy.

Astles, K.L., Gibbs, P.J., Steffe, A.S., Green, M., 2009. A qualitative risk-based assessment of impacts on marine habitats and harvested species for a data deficient wild capture fishery. Biol. Conserv. 142 (11), 2759-2773. https://doi.org/ 10.1016/j.biocon.2009.07.006.

Ban, N.C., Alidina, H.M., Ardron, J.a., 2010. Cumulative impact mapping: advances, relevance and limitations to marine management and conservation, using Canada's Pacific waters as a case study. Mar. Policy 34 (5), 876-886. https://doi.org/10.1016/j. marpol.2010.01.010.

Ban, S.S., Pressey, R.L., Graham, N.A.J., 2014. Assessing interactions of multiple stressors when data are limited: a Bayesian belief network applied to coral reefs. Glob. Environ. Chang. 27, 64-72.

Barmawidjaja, D.M., Van der Zwaan, G.J., Jorissen, F.J., Puskaric, S., 1995. 150 years of eutrophication in the northern Adriatic Sea: evidence from a benthic foraminiferal record. Mar. Geol. 122 (4), 367-384.

Bastari, A., Micheli, F., Ferretti, F., Pusceddu, A., Cerrano, C., 2016. Large marine protected areas (LMPAs) in the Mediterranean Sea: the opportunity of the Adriatic Sea. Mar. Policy 68, 165-177

Bax, N., Williamson, A., Aguero, M., Gonzalez, E., Geeves, W., 2003. Marine invasive alien species: a threat to global biodiversity. Mar. Policy 27 (4), 313-323.

Berry, P.M., Brown, S., Chen, M., Kontogianni, A., Rowlands, O., Simpson, G., Skourtos, M., 2015. Cross-sectoral interactions of adaptation and mitigation measures. Clim. Chang. 128 (3-4), 381-393. https://doi.org/10.1007/s10584-014-1214-0.

Bevilacqua, S., Guar, G., Farella, G., Terlizzi, A., Fraschetti, S., 2018. A regional assessment of cumulative impact mapping on Mediterranean coralligenous outcrops. Scientific Reports, 2-12 https://doi.org/10.1038/s41598-018-20297-1 (January).

Borja, A., Elliott, M., Andersen, J.H., Berg, T., Carstensen, J., Halpern, B.S., ... Martin, G., 2016. Overview of integrative assessment of marine systems: the ecosystem approach in practice. Front. Mar. Sci. 3, 20.

Breithaupt, H., 2003. Aliens on the shores: biodiversity and national economies are being threatened by the invasion of non-native species. EMBO Rep. 4 (6), 547-550.

Breton F., Ivanov E., N. M. (2014). D4.2 Report, accompanying database and supporting materials on LEAC Methodology and how to apply it in CASES.

Brown, C.J., Saunders, M.I., Possingham, H.P., Richardson, A.J., 2014. Interactions between global and local stressors of ecosystems determine management effectiveness in cumulative impact mapping. Divers. Distrib. 20 (5), 538-546. https://doi.org/10.1111/ ddi.12159.

Buljan, M., Zore-Armanda, M., 1979. Hydrographic Properties of the Adriatic Sea in the Period From 1965 Through 1970 (Institut za oceanografiju i ribarstvo).

Canu, D.M., Solidoro, C., Cossarini, G., Giorgi, F., 2010. Effect of global change on bivalve rearing activity and the need for adaptive management. Clim. Res. 42 (1), $13-26$.

Canu, D.M., Campostrini, P., Riva, S.D., Pastres, R., Pizzo, L., Rossetto, L., Solidoro, C., 2011. Addressing sustainability of clam farming in the Venice Lagoon. Ecol. Soc. 16 (3).

Canu, D.M., Ghermandi, A., Nunes, P.A.L.D., Lazzari, P., Cossarini, G., Solidoro, C., 2015. Estimating the value of carbon sequestration ecosystem services in the Mediterranean Sea: an ecological economics approach. Glob. Environ. Chang. 32, 87-95.

Carman, K.R., Fleeger, J.W., Pomarico, S.M., 1997. Response of a benthic food web to hydrocarbon contamination. Limnol. Oceanogr. 42 (3), 561-571.

Casellato, S., Stefanon, A., 2008. Coralligenous habitat in the northern Adriatic Sea: an overview. Mar. Ecol. 29 (3), 321-341.

Cerrano, C., Bakran-Petricioli, T., Bastari, A., Fraschetti, S., Huete-Stauffer, C., Ferretti, F., .. Valisano, L. (2016). Adriatic Sea: Description of the Ecology and Identification of the Areas that May Deserve to be Protected. United Nations Environment Programme/ Mediterranean Action Plan (UNEP/MAP)-Regional Activity Centre for Specially Protected Areas (RAC/SPA), Tunis, Urednici: Cebrian, D., Requena, S.

Choquet, G. (1954). Theory of capacities. In Annales de l'institut Fourier (Vol. 5, pp. 131-295). Institut Fourier.

Crain, C.M., Kroeker, K., Halpern, B.S., 2008. Interactive and cumulative effects of multiple human stressors in marine systems. Ecol. Lett. 11 (12), 1304-1315. https://doi.org/ 10.1111/j.1461-0248.2008.01253.x.

De Poorter, M., Darby, C., MacKay, J., 2010. Marine Menace. IUCN, Alien Invasive Species in the Marine Environment.

Degobbis, D., 1989. Increased eutrophication of the northern Adriatic Sea: second act. Mar. Pollut. Bull. 20 (9), 452-457.

Degobbis, D., Precali, R., Ivancic, I., Smodlaka, N., Fuks, D., Kveder, S., 2000. Long-term changes in the northern Adriatic ecosystem related to anthropogenic eutrophication. Int. J. Environ. Pollut. 13 (1-6), 495-533.

Delavar, M.R., Moradi, M., Moshiri, B., 2015. Earthquake vulnerability assessment for hospital buildings using a GIS-based group multi criteria decision making approach: a case study of Tehran, Iran. ISPRS-International Archives of the Photogrammetry, Remote Sensing and Spatial Information Sciences, XL-1-W5, pp. 153-157 https://doi. org/10.5194/isprsarchives-XL-1-W5-153-2015.

Demirel, T., Öner, S.C., Tüzün, S., Deveci, M., Öner, M., Demirel, N.Ç., 2018. Choquet integral-based hesitant fuzzy decision-making to prevent soil erosion. Geoderma 313, 276-289.

Depellegrin, D., Menegon, S., Farella, G., Ghezzo, M., Gissi, E., Sarretta, A., ... Barbanti, A., 2017. Multi-objective spatial tools to inform maritime spatial planning in the Adriatic Sea. Sci. Total Environ. 609, 1627-1639. 
Douvere, F., 2008. The importance of marine spatial planning in advancing ecosystembased sea use management. Mar. Policy 32 (5), 762-771. https://doi.org/10.1016/j. marpol.2008.03.021.

Druon, J.-N., Schrimpf, W., Dobricic, S., Stips, A., 2004. Comparative assessment of largescale marine eutrophication: North Sea area and Adriatic Sea as case studies. Mar. Ecol. Prog. Ser. 272, 1-23.

EC. (2005). Proposal for a Directive of the European Parliament and of the Council Establishing a Framework for Community Action in the Field of Marine Environmental Policy (Marine Strategy Directive) [SEC(2005) 1290], 0211, 31.

EC. (2008). Directive 2008/56/EC of the European Parliament and of the Council of 17 June 2008 Establishing a Framework for Community Action in the Field of Marine Environmental Policy (Marine Strategy Framework Directive)., 19-40.

EEA, 1999. Environmental Indicators: Typology and Overview (European Environmental).

Elliott, M., Borja, Á., McQuatters-Gollop, A., Mazik, K., Birchenough, S., Andersen, J.H., .. Peck, M., 2015. Force majeure: will climate change affect our ability to attain Good Environmental Status for marine biodiversity? Mar. Pollut. Bull. 95 (1), 7-27. https://doi.org/10.1016/j.marpolbul.2015.03.015.

European Parliament, 2001. Directive 2001/42/EC of the European Parliament and of the Council of 27 June 2001, on the assessment of the effects of certain plans and programmes on the environment. Off. J. Eur. Communities 197, 30-37.

Ferraro, G., Bernardini, A., David, M., Meyer-Roux, S., Muellenhoff, O., Perkovic, M., .. Topouzelis, K., 2007. Towards an operational use of space imagery for oil pollution monitoring in the Mediterranean basin: a demonstration in the Adriatic Sea. Mar. Pollut. Bull. 54 (4), 403-422.

Foden, J., Rogers, S.I., Jones, A.P., Rogers, S., 2011. Human pressures on UK seabed habitats: a cumulative impact assessment. Mar. Ecol. Prog. Ser. 428, 33-47.

Foley, M.M., Halpern, B.S., Micheli, F., Armsby, M.H., Caldwell, M.R., Crain, C.M., ... Steneck, R.S., 2010. Guiding ecological principles for marine spatial planning. Mar. Policy 34 (5), 955-966. https://doi.org/10.1016/j.marpol.2010.02.001.

Furlan, E., Torresan, S., Critto, A., Marcomini, A., 2018. Spatially explicit risk approach for multi-hazard assessment and management in marine environment: the case study of the Adriatic Sea. Sci. Total Environ. 618, 1008-1023.

Gain, A.K., Giupponi, C., 2015. A dynamic assessment of water scarcity risk in the Lower Brahmaputra River Basin: an integrated approach. Ecol. Indic. 48, 120-131.

Galli, G., Solidoro, C., Lovato, T., 2017. Marine heat waves hazard 3D maps and the risk for low motility organisms in a warming Mediterranean Sea. Front. Mar. Sci. 4, 136.

Gamulin-Brida, H., 1974. Biocoenoses benthiques de la mer Adriatique (Institut za oceanografiju i ribarstvo)

Giove, S., Brancia, A., Satterstrom, F. K., \& Linkov, I. (2009). Decision support systems and environment: role of MCDA. In Decision Support Systems for Risk-based Management of Contaminated Sites (pp. 1-21). Springer.

Gissi, E., Menegon, S., Sarretta, A., Appiotti, F., Maragno, D., Vianello, A., ... Barbanti, A., 2017. Addressing Uncertainty in Modelling Cumulative Impacts Within Maritime Spatial Planning in the Adriatic and Ionian Region, 1-30.

Giupponi, C., Giove, S., Giannini, V., 2013. A dynamic assessment tool for exploring and communicating vulnerability to floods and climate change. Environ. Model Softw. 44, 136-147.

Grabisch, M., 1996. The application of fuzzy integrals in multicriteria decision making. Eur. J. Oper. Res. 89 (3), 445-456. https://doi.org/10.1016/0377-2217(95) 00176-X.

Grabisch, M., Roubens, M., 2000. Application of the Choquet integral in multicriteria decision making. Fuzzy Measures and Integrals-Theory and Applications 348-374.

Guidetti, P., Lorenti, M., Buia, M.C., Mazzella, L., 2002. Temporal dynamics and biomass partitioning in three Adriatic seagrass species: Posidonia oceanica, Cymodocea nodosa, Zostera marina. Mar. Ecol. 23 (1), 51-67.

Halpern, B.S., Walbridge, S., Selkoe, K.A., Kappel, C.V, Micheli, F., D’Agrosa, C., ... Watson, R. 2008. A global map of human impact on marine ecosystems. Science 319 (5865), 948-952. https://doi.org/10.1126/science.1149345 (New York, N.Y.).

Hayes, E.H., Landis, W.G., 2004. Regional ecological risk assessment of a near shore marine environment: Cherry Point, WA. Human and Ecological Risk Assessment: An International Journal 10 (2), 299-325. https://doi.org/10.1080/10807030490438256.

HELCOM. (2017). The assessment of cumulative impacts using the Baltic Sea Pressure Index and the Baltic Sea Impact Index - supplementary report to the first version of the HELCOM "State of the Baltic Sea" report 2017. Available at: http:// stateofthebalticsea.helcom.fi/about-Helcom-and-the-Assessment/downloads-andData/.

IMO/UNEP, 2011. Regional Information System; Part C2, Statistical Analysis-Alerts and Accidents Database, REMPEC (February 2011).

IPCC. (2014). Summary for policy makers. In: Climate Change 2014: Impacts, Adaptation, and Vulnerability. Part A: Global and Sectoral Aspects. Contribution of Working Group II to the Fifth Assessment Report of the Intergovernmental Panel on Climate Change [Field, C.B., 1-32. doi:https://doi.org/10.1016/j.renene.2009.11.012.

ISPRA. (2012a). Strategia per l'ambiente marino. Valutazione iniziale. Sottoregione mar Adriatico. Arricchimento di nutrienti e sostanza organica. Documenti per la consultazione pubblica del 2012. Bozza, 10 Maggio 2012.

ISPRA. (2012b). Strategia per l'ambiente marino. Valutazione iniziale. Sottoregione mar Adriatico. Danno fisico. Documenti per la consultazione pubblica del 2012. Bozza, 10 Maggio 2012.

ISPRA. (2012c). Strategia per l'ambiente marino. Valutazione iniziale. Sottoregione mar Adriatico. Perdita fisica. Documenti per la consultazione pubblica del 2012. Bozza, 10 Maggio 2012

ISPRA. (2012d). Strategia per l'ambiente marino. Valutazione iniziale. Sottoregione mar Adriatico. Rifiuti marini. Documenti per la consultazione pubblica del 2012. Bozza, 10 Maggio 2012., 1-10.

Kalbfleisch, J.G., 1985. Probability and statistical inference: volume 1: probability. Springer Texts in Statistics-Sep 9, 1985.
Kappel, C. V, Halpern, B. S., \& Napoli, N. (2012). Mapping cumulative impacts of human activities on marine ecosystems. Coastal and Marine Spatial Planning. Research Report \#03.NCEAS.12, (January).

Keller, R.P., Drake, J.M., Drew, M.B., Lodge, D.M., 2011. Linking environmental conditions and ship movements to estimate invasive species transport across the global shipping network. Divers. Distrib. 17 (1), 93-102.

Kelly, C., Ellis, G., Flannery, W., 2018. Conceptualising change in marine governance: learning from transition management. Mar. Policy 95 (October 2017), 24-35. https://doi.org/10.1016/j.marpol.2018.06.023.

Kingston, P.F., 2002. Long-term environmental impact of oil spills. Spill Science \& Technology Bulletin 7 (1-2), 53-61.

Kirby, M.F., Law, R.J., 2010. Accidental spills at sea-risk, impact, mitigation and the need for co-ordinated post-incident monitoring. Mar. Pollut. Bull. 60 (6), 797-803.

Koce, J.D., Vilhar, B., Bohanec, B., Dermastia, M., 2003. Genome size of Adriatic seagrasses. Aquat. Bot. 77 (1), 17-25.

Korpinen, S., Meski, L., Andersen, J.H., Laamanen, M., 2012. Human pressures and their potential impact on the Baltic Sea ecosystem. Ecol. Indic. 15 (1), 105-114. https://doi. org/10.1016/j.ecolind.2011.09.023.

Kristensen, P., 2004. The DPSIR Framework, Workshop on a Comprehensive/Detailed Assessment of the Vulnerability of Water Resources to Environmental Change in Africa Using River Basin Approach. UNEP Headquarters, Nairobi, Kenya.

Kuhlenkamp, R., \& Kind, B. (2018). Introduction of non-indigenous species. In Handbook on Marine Environment Protection (pp. 487-516). Springer.

Lazzari, P., Mattia, G., Solidoro, C., Salon, S., Crise, A., Zavatarelli, M., ... Vichi, M., 2014. The impacts of climate change and environmental management policies on the trophic regimes in the Mediterranean Sea: scenario analyses. J. Mar. Syst. 135, 137-149.

Lazzari, P., Solidoro, C., Salon, S., Bolzon, G., 2016. Spatial variability of phosphate and nitrate in the Mediterranean Sea: a modeling approach. Deep-Sea Res. I Oceanogr. Res. Pap. 108, 39-52.

Lipej, L., Dulčić, J., 2004. Fish biodiversity in the Adriatic Sea. Griffiths, Huw I; Kryštufek, Boris; Reed, Jane M. Balkan Biodiversity: Pattern and Process in the European Hotspot. Springer. ISBN 978, 1-4020.

Lovato T., Vichi M., O. P. (2013). High resolution simulations of Mediterranean Sea physical oceanography under current and scenario climate conditions: model description, assessment and scenario analysis. Research Papers, Issue RP0207, (December 2013).

Malczewski, J., 1999. GIS and Multicriteria Decision Analysis. John Wiley \& Sons.

Mendelssohn, I.A., Andersen, G.L., Baltz, D.M., Caffey, R.H., Carman, K.R., Fleeger, J.W., ... Overton, E.B., 2012. Oil impacts on coastal wetlands: implications for the Mississipp River Delta ecosystem after the Deepwater Horizon oil spill. BioScience 62 (6), 562-574.

Menegon, S., Depellegrin, D., Farella, G., Gissi, E., Ghezzo, M., Sarretta, A., ... Barbanti, A. 2018a. A modelling framework for MSP-oriented cumulative effects assessment. Ecol. Indic. 91, 171-181.

Menegon, S., Depellegrin, D., Farella, G., Sarretta, A., Venier, C., Barbanti, A., 2018b. Addressing cumulative effects, maritime conflicts and ecosystem services threats through MSP-oriented geospatial webtools. Ocean Coast. Manag. 163 (July), 417-436. https://doi.org/10.1016/j.ocecoaman.2018.07.009.

Micheli, F., Halpern, B.S., Walbridge, S., Ciriaco, S., Ferretti, F., Fraschetti, S., ... Rosenberg, A a., 2013. Cumulative human impacts on Mediterranean and Black Sea marine ecosystems: assessing current pressures and opportunities. PLoS One 8 (12), e79889. https://doi.org/10.1371/journal.pone.0079889.

Munari, C., Corbau, C., Simeoni, U., Mistri, M., 2016. Marine litter on Mediterranean shores: analysis of composition, spatial distribution and sources in north-western Adriatic beaches. Waste Manag. 49, 483-490.

Murofushi, T., Sugeno, M., 1989. An interpretation of fuzzy measures and the Choquet integral as an integral with respect to a fuzzy measure. Fuzzy Sets Syst. 29 (2), 201-227.

Nordemar, I., Nyström, M., Dizon, R., 2003. Effects of elevated seawater temperature and nitrate enrichment on the branching coral Porites cylindrica in the absence of particulate food. Mar. Biol. 142 (4), 669-677.

Oddo, P., Bonaduce, A., Pinardi, N., Guarnieri, A., 2014. Sensitivity of the Mediterranean Sea level to atmospheric pressure and free surface elevation numerical formulation in NEMO. Geosci. Model Dev. 7 (6), 3001-3015. https://doi.org/10.5194/gmd-73001-2014.

Okey, T.a., Agbayani, S., Alidina, H.M., 2015. Mapping ecological vulnerability to recent climate change in Canada's Pacific marine ecosystems. Ocean \& Coastal Management 106, 35-48. https://doi.org/10.1016/j.ocecoaman.2015.01.009.

Ondiviela, B., Losada, I.J., Lara, J.L., Maza, M., Galván, C., Bouma, T.J., van Belzen, J., 2014. The role of seagrasses in coastal protection in a changing climate. Coast. Eng. 87, 158-168. https://doi.org/10.1016/j.coastaleng.2013.11.005.

Paoli, J.N., Strauss, O., Tisseyre, B., Roger, J.M., Guillaume, S., 2007. Spatial data fusion for qualitative estimation of fuzzy request zones: application on precision viticulture. Fuzzy Sets Syst. 158 (5), 535-554. https://doi.org/10.1016/j.fss.2006.10.019.

Patrício J., Teixeira H., Borja A., Elliott M., Berg T., Papadopoulou N., Smith C., Luisetti T., Uusitalo L., Wilson C., Mazik K., Niquil N., Cochrane S., Andersen J.H., Boyes S., Burdon D., Carugati L., Danovaro R., H. N. (2014). DEVOTES Recommendations for the Implementation of the Marine Strategy Framework Directive. Deliverable 1.5, 71 pp. DEVOTES project. JRC92131.

Patrício, J., Elliott, M., Mazik, K., Papadopoulou, N., Smith, C., 2016. DPSIR-two decades of trying to develop a unifying framework for marine environmental management? Front. Mar. Sci. 3, 177.

Pavlakis, P., Tarchi, D., \& Sieber, A. J. (2001). On the monitoring of illicit vessel discharges using spaceborne SAR remote sensing-a reconnaissance study in the Mediterranean Sea. In Annales des télécommunications (Vol. 56, pp. 700-718). Springer.

Pizzol, L., Critto, A., Agostini, P., Marcomini, A., 2011. Regional risk assessment for contaminated sites part 2: ranking of potentially contaminated sites. Environ. Int. 37 (8), 1307-1320. 
Policy Research Corporation, 2011. The Potential of Maritime Spatial Planning in the Mediterranean Sea. Case study Report, The Adriatic Sea.

Ramieri, E., Andreoli, E., Fanelli, A., Artico, G., Bertaggia, R., 2014. Methodological handbook on Maritime Spatial Planning in the Adriatic Sea. Final Report of Shape Project WP4 "Shipping Towards Maritime Spatial Planning", Issuing Date: 10th (February).

Riahi, K., Rao, S., Krey, V., Cho, C., Chirkov, V., Fischer, G., ... Rafaj, P., 2011. RCP 8.5-a scenario of comparatively high greenhouse gas emissions. Clim. Chang. 109 (1-2), 33-57.

Rizzi, J., Torresan, S., Critto, A., Zabeo, A., Brigolin, D., Carniel, S., ... Marcomini, A., 2015. Climate change impacts on marine water quality: the case study of the Northern Adriatic sea. Mar. Pollut. Bull. https://doi.org/10.1016/j.marpolbul.2015.06.037.

Rizzi, J., Torresan, S., Zabeo, A., Critto, A., Tosoni, A., Tomasin, A., Marcomini, A., 2017. Assessing storm surge risk under future sea-level rise scenarios: a case study in the North Adriatic coast. J. Coast. Conserv. 1-19.

Ronco, P., Bullo, M., Torresan, S., Critto, A. Olschewski, R., Zappa, M., Marcomini, A, 2015. KULTURisk regional risk assessment methodology for water-related natural hazardspart 2: application to the Zurich case study. Hydrol. Earth Syst. Sci. 19 (3), 1561-1576.

Rossi, N., Ciavatta, C., \& Sequi, P. (1992). Contribution of agricultural land in the Po Valley to coastal eutrophication of the Adriatic Sea. In Marine Coastal Eutrophication (pp. 349-364). Elsevier.

Salomidi, M., Katsanevakis, S., Borja, Á., Braeckman, U., Damalas, D., Galparsoro, I., .. Pipitone, C., 2012. Assessment of goods and services, vulnerability, and conservation status of European seabed biotopes: a stepping stone towards ecosystem-based marine spatial management. Mediterr. Mar. Sci. 13 (1), 49-88.

Sangiorgi, F., Donders, T.H., 2004. Reconstructing 150 years of eutrophication in the north-western Adriatic Sea (Italy) using dinoflagellate cysts, pollen and spores. Estuar. Coast. Shelf Sci. 60 (1), 69-79.

Sanseverino, I., Conduto, D., Pozzoli, L., Dobricic, S., Lettieri, T., 2016. Algal Bloom and Its Economic Impact. European Commission, Joint Research Centre Institute for Environment and Sustainability.

Solidoro, C., Bastianini, M., Bandelj, V., Codermatz, R., Cossarini, G., Canu, D.M., ... Trevisani, S., 2009. Current state, scales of variability, and trends of biogeochemical properties in the northern Adriatic Sea. Journal of Geophysical Research: Oceans 114 (C7).

Sperotto, A., Torresan, S., Gallina, V., Coppola, E., Critto, A., Marcomini, A., 2016. A multidisciplinary approach to evaluate pluvial floods risk under changing climate: the case study of the municipality of Venice (Italy). Sci. Total Environ. 562, 1031-1043.

Stelzenmüller, V., Lee, J., South, A., Rogers, S.I., 2009. Quantifying cumulative impacts of human pressures on the marine environment: a geospatial modelling framework. Mar. Ecol. Prog. Ser. 398, 19-32. https://doi.org/10.3354/meps08345.

Stelzenmüller, V., Lee, J., Garnacho, E., Rogers, S.I., 2010. Assessment of a Bayesian Belief Network-GIS framework as a practical tool to support marine planning. Mar. Pollut. Bull. 60 (10), 1743-1754. https://doi.org/10.1016/j.marpolbul.2010.06.024.

Strafella, P., Fabi, G., Spagnolo, A., Grati, F., Polidori, P., Punzo, E., ... Scarcella, G., 2015. Spatial pattern and weight of seabed marine litter in the northern and central Adriatic Sea. Mar. Pollut. Bull. 91 (1), 120-127. https://doi.org/10.1016/j. marpolbul.2014.12.018.

Suaria, G., Aliani, S., 2014. Floating debris in the Mediterranean Sea. Marine Pollution Bulletin, article in 1-2, 494-504. https://doi.org/10.1016/j.marpolbul.2014.06.025.
Suaria, G., Avio, C.G., Mineo, A., Lattin, G.L., Magaldi, M.G., Belmonte, G., ... Aliani, S., 2016. The Mediterranean Plastic Soup: synthetic polymers in Mediterranean surface waters. Sci. Rep. 6, 37551.

Sundbäck, K., Petersen, D.G., Dahllöf, I., Larson, F., 2007. Combined Nutrient-Toxicant Effects on a Shallow-water Marine Sediment System: Sensitivity and Resilience of Ecosystem Functions, 330, 13-30.

Torquemada, Y.F., Durako, M.J., Lizaso, J.L.S., 2005. Effects of salinity and possible interactions with temperature and $\mathrm{pH}$ on growth and photosynthesis of Halophila johnsonii Eiseman. Mar. Biol. 148, 251-260. https://doi.org/10.1007/s00227-005-0075-5.

Torresan, S., Critto, A., Rizzi, J., Marcomini, A., 2012. Assessment of coastal vulnerability to climate change hazards at the regional scale: the case study of the North Adriatic Sea. Natural Hazards and Earth System Science 12 (7), 2347-2368. https://doi.org/ 10.5194/nhess-12-2347-2012.

Torresan, S., Critto, A., Rizzi, J., Zabeo, A., Furlan, E., Marcomini, A., 2016. DESYCO: a decision support system for the regional risk assessment of climate change impacts in coastal zones. Ocean \& Coastal Management 120, 49-63. https://doi.org/10.1016/j. ocecoaman.2015.11.003.

Trincardi, F., Cattaneo, A., Asioli, A., Correggiari, A., Langone, L., 1996. Stratigraphy of the late-Quaternary deposits in the central Adriatic basin and the record of short-term climatic events. Memorie-Istituto Italiano Di Idrobiologia 55, 39-70.

Van Straaten, L., 1970. Holocene and late-Pleistocene sedimentation in the Adriatic Sea. Geol. Rundsch. 60 (1), 106-131.

Vilà, M., Basnou, C., Pyšek, P., Josefsson, M., Genovesi, P., Gollasch, S., ... Roy, D., 2010. How well do we understand the impacts of alien species on ecosystem services? A panEuropean, cross-taxa assessment. Front. Ecol. Environ. 8 (3), 135-144.

Walther, G.-R., Roques, A., Hulme, P.E., Sykes, M.T., Pyšek, P., Kühn, I., ... Bugmann, H., 2009. Alien species in a warmer world: risks and opportunities. Trends Ecol. Evol. 24 (12), 686-693.

Waycott, M., Collier, C., Mcmahon, K., Ralph, P., Mckenzie, L., Udy, J., Grech, A., 2007. Vulnerability of seagrasses in the Great Barrier Reef to climate change. Climate Change and the Great Barrier Reef: A Vulnerability Assessment 193-236.

Zabeo, A., Semenzin, E., Torresan, S., Gottardo, S., Pizzol, L., Rizzi, J., ... Marcomini, A., 2010. Fuzzy logic based IEDSSs for environmental risk assessment and management (Strategy)

Zabeo, A., Pizzol, L., Agostini, P., Critto, A., Giove, S., Marcomini, A., 2011. Regional risk assessment for contaminated sites part 1 : vulnerability assessment by multicriteria decision analysis. Environ. Int. 37 (8), 1295-1306. https://doi.org/10.1016/j. envint.2011.05.005.

Zald, A.E., Summer, S., Wade, T., 2006. A to Z GIS: An Illustrated Dictionary of Geographic Information Systems.

Zore-Armanda, M. (1983). 10. Oceanographic time series in the Adriatic Sea. Time Series of Ocean Measurements, 43.

Zunino, S., Canu, D.M., Bandelj, V., Solidoro, C., 2017. Effects of ocean acidification on benthic organisms in the Mediterranean Sea under realistic climatic scenarios: a metaanalysis. Reg. Stud. Mar. Sci. 10, 86-96. 